\title{
The UK Food Retail "Race for Space" and Market Saturation: A Contemporary Review
}

Authors' accepted version (August 2013) for publication in The International Review of Retail, Distribution \& Consumer Research

Steve Wood ${ }^{1}$ and Dave McCarthy ${ }^{2}$

${ }^{1}$ Surrey Business School, University of Surrey, Guildford, Surrey GU2 7XH, United Kingdom sm.wood@surrey.ac.uk

${ }^{2}$ Investec Securities, 2 Gresham Street, London, EC2V 7QP, United Kingdom

dave.mccarthy@investec.co.uk

\section{Acknowledgements}

We are grateful to Jonathan Reynolds, Andrew Alexander and Alan Hallsworth on comments of earlier drafts of this paper. We also appreciate the helpful feedback of two anonymous referees for the EAERCD 2013 conference and a further two referees for this journal. As always, all errors, where they exist, remain our own. 


\section{The UK Food Retail "Race for Space” and Market Saturation: A Contemporary Review}

This conceptual review paper explores food retail space saturation in the UK in the light of an apparent recent peak of store space growth, an inferred decline of the hypermarket format, and, in particular, the stagnation and subsequent deterioration in performance of the UK market leader, Tesco. Despite saturation being widely discussed by retail executives and analysts, the last significant academic work in this area occurred in the mid-1990s. In this paper, we develop an understanding of retail saturation that rests on a spatial conceptualisation of retail development at a local catchment level and rationalise why, and in what ways, saturation manifests itself through sales impacts and cannibalisation. In the process, we analyse the differing local effects of new store openings, store extensions and format innovation to illustrate how saturation is contingent upon local catchment conditions, competitive interactions and the particular geography of retail brands and formats. Although a significant slow-down in new store construction may be a logical response at the level of the industry, this may not necessarily be the case for individual retail firms.

Keywords: retail saturation, store format, food retailing, location planning, retail geography

\section{Introduction}

The increase in UK food retail space - "proposed", "with planning consent" and "under construction" - has, until recently, surprisingly bucked the trend of the wider slowdown in retail property investment. As research by CB Richard Ellis (2011; 2012a; 2012b; 2013) suggests, while speculative shopping centre and retail park development "in the pipeline" cumulatively declined from the start of the economic crisis (September 2007) to 2012 by just over 7 million sq ft, the overall grocery pipeline grew by over $15.6 \mathrm{~m} \mathrm{sq} \mathrm{ft}(54 \%)$, with retailers exploiting modest property prices given the depressed economic conditions. Such data noticeably predicated media reports suggestive of thousands of more superstores and hypermarkets flooding the UK's towns (e.g. The Guardian, 2011). Yet very soon after this, at the start of 2012, the development bubble appeared - perhaps not to exactly burst - but at least deflate markedly in the light of the main protagonist of intensive space expansion, Tesco, announcing disappointing UK results, after five years of stagnant performance against the market. In response, the UK retail market leader detailed a shift from an aggressive store space expansion strategy, particularly involving large stores and hypermarkets, to greater 
investment in its existing store portfolio's appearance, staffing and customer service. Other major food retailers similarly detailed reduced space expansion plans and there were subsequent wider discussions across the industry regarding the apparent saturation of UK grocery retailing - something that echoed debates in the 1990s across retail management and retail geography (Guy, 1994; 1996; Langston et al., 1997; 1998; Lord, 2000; Poole et al., 2006). Interestingly though, there has been no recent conceptualization of retail saturation within the research literature, despite its clearly topical nature. Therefore, this paper seeks to contribute to the debate concerning store expansion and retail saturation by offering a reconceptualization and elaboration of saturation at the level of the local catchment and of the firm, in particular focusing on inter-firm competitive issues and the potential contribution of productivity improvements at the individual store level. The paper is structured as follows:

First, we review recent developments within food retail store growth and associated performance to explain why retail saturation is viewed by many as imminent or currently occurring in the UK. Second, by engaging with the academic research on this issue, we develop a conceptual understanding of retail saturation effects at the local catchment level. Certainly the theoretical nature of such analysis may be regarded by some as a limitation, but we argue that this allows us to rationalise why, and in what ways, the phenomenon might manifest itself. Such analysis explores the effects of new store opening, store extensions and new format development, which serves to underline the situationally dependent nature of saturation and why it is closer for some operators than for others. Third, using this conceptual backdrop, we explain why the significant slow-down in store development may be a logical response at the industry level but not necessarily for individual retailers across the sector. This is important to understand given the commitments that numerous retailers have publicly made to slowing their site acquisition and store construction.

\section{The geography of recent store development, retail saturation and the apparent decline of the hypermarket}

The rise in grocery retail development since the mid-2000s to 2012 was remarkable given the wider economic downturn and in many ways mirrored the so-called "store wars" period of the late 1980s and early 1990s, when "the major UK food retailers became locked into strategies of accumulation in which capital investment in new store expansion programmes became the all-consuming engine of corporate growth" (Wrigley, 1998, 15). This earlier (late 1980s and early 1990s) phase of intensive expansion was brought to an abrupt halt in the mid-1990s due to problems of property over-valuation, non-recoverable initial investment, 
the treatment of capitalised interest and the wider implications of sunk costs in corporate strategy (see Guy, 1995, 1999; Wrigley, 1996). The more recent period of store expansion is represented in Figure 1, characterised by a particular increase in development schemes "with consent" though this has fed through to less of an increase in grocery developments "under construction" than may perhaps have been expected. In general, the continued rate of new store expansion may have been partly driven by concerns that any local "Competition Test", a recommendation of the Competition Commission's 2008 inquiry into the grocery market, would restrict subsequent expansion opportunities (see Hughes et al., 2009). However, such overviews of aggregate level store growth themselves disguise substantial differences between retailers ( $c f$. Sparks, 2011), with Tesco, at the time of writing, accounting for $30.1 \%$ of the food retail market $c f$. ASDA Walmart (17.0\%); Sainsbury's (16.5\%) and Morrisons (11.7\%) (Kantar Worldpanel, 2013). These disparities lead to different implications for specific fascias in terms of the potential (or not) for store growth at the local level - as we explore later.

Figure 1 about here

Unlike the classic "store wars" episode depicted by Wrigley (1994), the recent period of growth occurred under the auspices of a considerably tightened retail land-use planning regulatory framework. The progressive tightening of retail land-use planning policy since the permissive approach to out-of-town retail development across the UK in the 1980s is expertly explained elsewhere (Guy, 2007), though it is important to note the landmark revision to England's Planning Policy Guidance Note 6 (PPG6) in 1996 that signalled the start of a robust "town centres first" governance of retail development planning through the sequential test that prioritised retail investment in established centres, with similar tightening occurring elsewhere across the UK (see Findlay and Sparks, 2006; Wood et al., 2006; Wrigley, 1998). Indeed, Morelli (2007) argues that the "golden age" of British retailing effectively ended in the mid-1990s, just as more restrictive assessments of development criteria were introduced. The essence of the "town centres first" approach has continued through the evolution of retail land-use planning policy across the UK, and in England specifically through Planning Policy Statement 6 (PPS6) in 2005, Planning Policy Statement 4 (PPS4) in 2009 and most recently the development of The National Planning Policy Framework (NPPF), published in March 2012 (see Barclay, 2012 for an accessible contemporary summary). 
Since then, academic research has assessed the implications for food retailer development, in particular noting the necessity for retailers to become increasingly flexible in their approaches to expansion (Guy and Bennison, 2007; Wood et al., 2006; 2010) - through the adaptation of development schemes to include stores constructed upon stilts to allow an increase in trading area with adequate car parking; the exploitation of a clause (since closed) in the Town and \& Country Planning Act (1990) that inadvertently allowed retailers to construct mezzanines in existing units; the entry into the convenience store market that is less burdened by land-use planning regulation; and an increased focus on smaller superstore and supermarket sites appropriate for town centre locations. Indeed, recent research has suggested that superstores located within, and on the edge of, town centres may have a positive effect on town centre resilience (Wrigley and Dolega, 2011; Wrigley et al., 2010; 2012) and that small shops in town centres and high streets have often themselves been resilient in the face of larger format corporate food store opening, contrary to fears emanating from the media and some pressure groups (Wrigley et al., 2009; Powe, 2012; Findlay and Sparks, 2012). However, analysis has suggested that the restrictive nature of retail land-use planning policies may have reduced retail productivity by as much as $20 \%$ (Cheshire et al., 2011; see also Griffith and Harmgart, 2012). In particular, retailers have found it challenging to construct larger, hypermarket stores (in excess of 60,000 sq ft) due to the "town centres first" thrust of retail planning policy:

\footnotetext{
"Large stores do not have to be developed out of centre, but in practice sites which are large enough for a store and its car-parking requirements are often difficult to obtain within town or district centres" (Guy and Bennison, 2007, 951).
}

Indeed, ASDA Walmart operates only 32 Supercentres (its hypermarket format) with its last one opened in Ellesmere Port as long ago as August 2006 (The Independent, 2012). In contrast, Tesco, the UK market leader, has developed a sizeable portfolio of its "Extra" hypermarket format, which currently accounts for $42 \%$ of its UK portfolio (see Figure 2). However, this has often been realised via transformative extensions of existing superstores located in catchments of high sales potential rather than organic growth at wholly new hypermarket development sites. As Figure 2 demonstrates, the amount of space increase of Extra stores accounted for by extensions has gradually decreased each year, yet at its peak accounted for $81 \%$ of the Extra format space increase in 2006/07. 
Given the background of a tightened regulatory framework within which food retailers have had to realise store expansion, it is remarkable that the geographical location of this growth continues to be oriented toward out of centre sites. Figure 3 compares grocery space under construction at town centre and out of town sites. This suggests that the town centres first policy has not been as influential in directing store development from out-of-town locations and towards town centres as had been hoped. Indeed, recent retail capital flight from town centres is well documented (Wrigley and Dolega, 2011) and has been exacerbated by the depressed economy since 2008.

Figures 3 about here

Another interesting aspect of the space growth has been the degree to which it has been driven by Tesco, the market leader. Table 1 compares the net new space between 20072012 , with the market leader accountable for $49 \%$ of net space additions by the Big 4 over the period.

Table 1 about here

In April 2012, following declining performance in the UK - a period that had capped off a five year stagnation of market share - Tesco announced that it was shifting significant capital investment from the creation of new space to the refurbishment of the existing store portfolio, accompanied by greater investment in store service levels that had been widely considered to have been cut, as the retailer's UK business had been employed as a so-called "cash cow" to subsidise expansion overseas. While $£ 1$ bn would be invested in the UK over the following financial year, it would cut the amount of new supermarket space by 40 per cent to $1.5 \mathrm{~m}$ square $\mathrm{ft}$ - as the Financial Times (2012a) suggested, "bringing to an end its era of massive expansion of big out of town supermarkets". In response, in its earnings announcement, J Sainsbury acknowledged that it was returning to more modest levels of store portfolio expansion, equating to annual expansion of about $1 \mathrm{~m} \mathrm{sq} \mathrm{ft}$. - it had added about $1.5 \mathrm{~m}$ sq $\mathrm{ft}$ of space through new stores or extensions to existing outlets in the year to March 2011 and $1.4 \mathrm{~m}$ sq ft in the year to March 2012 (Financial Times, 2012b). 
Such a slowdown in previously aggressive spatial expansion strategies led to widespread commentary and reflection from across the industry (e.g. Financial Times, 2012a; 2012e; The Guardian, 2012). In particular, the hypermarket format was identified for slower growth by Tesco; not least due to its extensive non-food space being particularly susceptible to online predation. In general, hypermarket sales densities have recently been disappointing (see Figure 4), while all the major retailers, with the exception of Morrisons, are experiencing a flattening of overall sales densities more widely (see Figure 5).

Figures $4 \& 5$ about here

The decreased emphasis on larger format stores was explained by Tesco CEO, Philip Clarke as follows:

\footnotetext{
"I am not calling the end of hypermarket. All I'm saying is that in the future, the likelihood is that stores that open will be largely food...Do we need to continue to build large hypermarkets in the UK when the internet is taking much of the growth in clothing and electronics? You can reach your own conclusions.” (Financial Times, 2012c)
}

Similar views concerning the decline of the hypermarket emanated from a spokesman for ASDA Walmart, suggesting that the "requirement to have those big out-of-town stores is somewhat negated by the ability to order online and have it delivered to your local shop." (The Independent, 2012). Finally, Morrisons Chief Executive, Dalton Philips, from a retailer not offering the largest retail format, was more extreme in his analysis, earmarking hypermarkets as a future "blip in the history of retail" (Retail Week, 2012a).

Such concerns infer that inappropriately sized store boxes will increasingly become a liability given the costs of operating low yield sales space - a trend that is equally impacting hypermarket operators on the continent (Financial Times, 2012d). Obviously remerchandising hypermarket units to increase the food offer ( $c f$. non-food) is a natural immediate response, even if this fails to address the core concern regarding a societal shift in the way UK consumers are shopping. Most recently, in March 2013, Tesco Commercial Director, Kevin Grace, optimistically suggested that its acquisition of family restaurant chain, Giraffe, and bakery, Euphorium, as well as its stake in coffee chain, Harris \& Hoole, will offer attractive services to partly plug this gap: "We have a great opportunity to rethink how we use the space in some of our larger stores." (Tesco plc, 2013). One related idea discussed 
at the time of writing (April 2013) is the introduction into stores of brands from outside the supermarket sector to, in the words of ASDA Walmart Chief Executive, Andy Clarke, "mop up surplus space" and constitute "mini high streets indoors" (Financial Times, 2013a).

Apart from the specific issues related to hypermarkets, the slowdown in new food retail store space has been conceived as a natural response to capacity outstripping demand an imbalance between the new space being planned and the predicted growth in consumer expenditure. Writing in the trade journal, Retail Week (2012b), Waitrose Managing Director, Mark Price cited short-term aggregate space growth and longer-term projections of expansion in the industry:

\begin{abstract}
"Just casting back over the last two years (2009 to 2011), the space dedicated to food and grocery in the UK grew by over $13 \%$, or a whopping 10.6 million sq $\mathrm{ft}$. The increase in sales value over the same period? Just $6.8 \%$. But it gets worse. Volume growth retail expenditure on food and grocery was $1.2 \%$. I'm afraid the picture doesn't improve if we look ahead to forecasts for 2011 to 2015. Space is predicted to grow by 19 million sq ft or just over $21 \%$. Sales value is tipped to go up by $14.3 \%$ and - no surprise - volume growth much lower, allowing for food price inflation, at a paltry 2.3\%" (Retail Week, 2012b).
\end{abstract}

Of course any readjustment to new rates of growth will not be instantaneous, given the lengthy time for development sites to be constructed. Superstore developments often involve multiple ownerships and lengthy planning consultation and approval processes, with Tesco especially, but also other operators, likely to have extensive so-called "land banks" of sites at various stages of the development pipeline (see Tesco plc, 2006). The Competition Commission (2008) notes that the four largest grocery retailers in the UK owned 520 land bank sites as of July 2006. While considered by some to be utilized as part of an anticompetitive strategy to restrict entry and exit into catchments (Financial Times, 2007) ${ }^{1}$, they certainly represent sizeable sunk costs that may be unrecoverable in the event of subsequent decisions not to proceed with development. In other words, some of the land already purchased by the leading retailers may be for inappropriately sized and located stores something underlined by Tesco's decision in April 2013 to write down the value of its UK property portfolio by $£ 804 \mathrm{~m}$, partly due to a decision not to build on more than 100 sites that the retailer owns and had earlier intended to develop into stores.

\footnotetext{
${ }^{1}$ The notion of food retailer land banks employed anti-competitively is unsupported by the Competition Inquiry (2008), page 149 , para. 7.81 .
} 
In the next section, we critically reflect on previous academic research on the issue of grocery market saturation. This research provides a platform upon which we conceptually examine the nature of sales impacts, cannibalisation and saturation at the spatial scale of the local catchment. Such analysis is instructive in exploring the situational nature of retail saturation that is driving subsequent changes in capital expenditure that have become increasingly evident at the macro industry level.

\section{Critically analysing the concept of retail store saturation}

The analysis of grocery market saturation was keenly discussed within the retailing research literature throughout the 1990s. This work ranged from exploring its likely arrival to indepth spatial analyses that identified regions within the UK that were particularly vulnerable. Such concerns have a long history. Writing in Retail \& Distribution Management in 1982, Peter Jones opened his article asking "Has the market for hypermarkets and superstores reached saturation?" with similar sentiments discussed for large formats at the end of the 1990s (Castrillo et al., 1998).

In reviewing the historical literature on retail saturation, Cliff Guy (1994) defines the concept as occurring when new store development reaches a certain level such that any further new stores will not be viable financially because they cannot gain sufficient share of the local market; or, that viability is possible only if existing stores are forced to close down. Clearly then, saturation is very much a local phenomenon that is dependent on individual catchments and their conditions, and, in turn, the interaction between retailers and consumers at the local level (Lord, 2000). Moreover, in a similar way as has been seen with oil and gas reserves, as technology and market changes, saturation (the end of reserves) is moveable. The Malthusian concept has therefore been somewhat nebulous, with Treadgold and Reynolds (1989) critiquing the notion of employing the hydrological metaphor of saturation to retailing at all. However, we concur with the view of Alexander and Morlock (1992) that it is useful to consider a concept that implies there is a point where superstore development becomes marginal, even if this may be variable across time, space and between retailers.

Such malleability of the concept of saturation is much discussed. Of course, additional quantitative demand may push the possibility of retail saturation further into the future - for example through new housing construction in growth regions and so-called "new" towns. But not all of these variables are purely location based. In addition, the retailers themselves can create additional customer demand through retail brand management, new format development and intelligent innovation, tailoring or curation of product offers - 
including targeted local ranging. Store choice dynamics can be considerably affected by (amongst other things) pricing and promotion strategy (Leszczyc et al., 2000); the nature of different customer shopping missions (Leszczyc et al., 2004; Reutterer and Teller, 2009); and by differences between retail formats (Wang et al., 2010). And, of course, identical retail offers may perform quite differently across space due to differences between their respective catchments, not least due to the characteristics of local customers. In this manner, the distinctive price positioning, format and product ranging of discount retailers such as Aldi and Lidl have driven continued growth, particularly in mid-market and less affluent locales, despite the saturation concerns of other, larger retailers in the market. The influence of retailer innovation on consumer demand is therefore considerable, as Poole et al. (2006, 2154) argue in concluding their analysis of pan-European grocery market saturation:

\footnotetext{
"[Leading multiple retailers] have a stronger brand presence and are thus more attractive to consumers; second, and relatedly, the depth and range of their products have themselves expanded the marketplace. At the same time, consumption is itself a function of, or in part derives from, the experience of retail provision that consumers face within their local area. The use consumers make of stores changes over time as a result of their experience of local provision and, in particular, changing patterns of local competition."
}

The tolerance for saturation or self-impacts will also vary between retailers. Holmes (2011) demonstrates in the case of Walmart that while contagious diffusion of store expansion and subsequent high density store networks can generate significant economies in operation (in terms of proximity to distribution centres to reduce "trucking costs"), management (as it is easier to oversee stores if they are closer together) and marketing (positive word-of-mouth and local brand awareness), there comes a point when "the benefits of increased economies of density come at the cost of cannibalization of existing stores" and therefore it makes little sense in constructing additional stores (ibid., 274). Holmes suggests that this tolerance for self-impacts is high with Walmart given the extent of these efficiencies, but there is a limit. Therefore, "getting right the extent to which new stores cannibalize sales of existing stores is crucial" (ibid., 267) - something challenging given the competitive interactions with other retailers that also have to be factored in. Understandably the leading UK food retailers dedicate considerable resource to location planning and sales forecasting to accurately estimate returns on investment and therefore quantify the value of development sites prior to any land sale auction (Wood and Reynolds, 2011; 2013). 
Furthermore, any empirical understanding of saturation should employ data on net total retail space rather than focus only on new space levels by the leading retailers ${ }^{2}$. As Langston et al. (1997) argue, a great deal of the expansion by the leading operators during Wrigley's (1991) so-called "golden age" of grocery store expansion came at the cost of closures of in-town stores seemingly unsuited to the new era of retailing, along with either the closure, liquidation or acquisition of vulnerable fascias and retail brands (Sparks, 1996a; 1996b). Concentrating only on the space increases of the leading operators without considering the closures of operators pressured by a cadre of growing national retail brands presents an exaggerated picture.

Repeatedly the academic literature has forecast the arrival of saturation only to see store numbers surpass these estimates (Castrillo et al., 1998; Jones, 1982; $c f$. Guy, 1994). While the UK has been subject to tightened retail land-use regulations which have effectively restricted the choice-set of potential development sites and locations, new entrants, such as the hard food discounters, including Aldi and Lidl, have intensified competition for customers (Burt and Sparks, 1994) but also increased the number of development sites, seemingly bringing closer any potential saturation (Guy, 1996). As such, the number of stores that trigger saturation has been somewhat of a "moving target". In part this is due to retailers pursuing value-adding strategies within stores to increase attractiveness (Duke, 1991), but also operators have become more efficient at constructing stores and then operationalizing them (Gustafsson et al., 2009), which has allowed units to be constructed on a lower cost base and profitably run with lower subsequent sales levels: effectively an increase in stores "at the margin" (Guy, 1995). This is important as it has enabled retailers to develop smaller infill stores in smaller towns that would previously have been regarded of insufficient size to support a superstore. As Langston et al. $(1998,51)$ noted, exploring "saturation in terms of market shares of individual companies" and "a bottom-up approach by examining market share in relation to individual locations" is prudent. Furthermore, as Burt and Sparks $(2003,243)$ suggest,

\footnotetext{
"As the sector or geographical area approaches high penetration or saturation such a process slows or reverses, with falls in superstore sales density encouraging new retail formats to be utilized" (our emphasis).
}

\footnotetext{
${ }^{2}$ We acknowledge that the data concerning retail space growth originating from CB Richard Ellis that is presented early in this paper itself fails to provide a net retail space growth figure. However, it is instructive in so far as it underlines the scale of investment in store estates over recent years.
} 
The effective "carrying capacity" of catchments has, in part, been increased through intensive format and ranging innovation (cf. Dawson, 2012; Reynolds et al., 2005; 2007), something particularly evident with corporate food retailers entering the convenience store market and driving through vast improvements in store quality, product offer and price that have seemingly created additional appeal and demand. Indeed, while Langston et al. $(1997 ; 1998)$ map the UK counties in terms of floor-space per household to delineate the most and least saturated regions, they conclude that "the idea of saturation must be approached with a clear appreciation that it is only ever likely to be a contingent feature of the grocery market" (Langston et al., 1998, 63).

\section{Considering the dynamics of saturation at a local level}

We now focus on representing the dynamics of store development at the local catchment level to aid us in understanding the implications of strategic portfolio management by the major food retailers. While our analysis is not empirical in nature, as seen in the work of Langston et al $(1997 ; 1998)$ or Poole et al. $(2002 \mathrm{a} ; 2002 \mathrm{~b} ; 2006)$ that provided spatial indexes of saturation, it is conceptually useful in explaining the changes in store catchments that accompany new store development, store extensions and new format development. Hence, with its emphasis on impacts from interactions with competitors and sales cannibalisation (self-impacts), we gain an understanding of the dynamics of retail saturation at the local scale. As with all conceptual work of this nature, it is deliberately simplistic and seeks to explore competitive interactions in theory to help us make sense of a more complicated open system. Of course, it is true that the scenarios that we explore below view catchments as closed systems, and thereby underplay any growth in demand in the catchment (for example, through housing growth) and also de-emphasise the nature of possible competitive responses beyond ones that are location based (for example, the effects of different formats, product offers, promotions etc.). Our focus here is therefore primarily on the interaction between stores situated in local catchments to explore and explain retail saturation. Given Langston et al.'s $(1998,49)$ argument that "the concept of saturation could only be understood in relation to the specific geographical context of local markets", it is logical that we should consider retail competition at the level of individual store catchments.

It is established that a store's attractiveness for a customer is partly a function of its accessibility and therefore the implied travel time (commonly considered with superstores as a drivetime). Put simply, a recent study of food retail competition and consumer choice summarised that: "[store attractiveness] was significantly greater if it was located at only 5- 
minutes travel than if it was at 15-minutes travel" (Clarke et al., 2012, 1907) ${ }^{3}$. However, the gravity of a store is also known to be affected by a range of issues such as store size, product offer and brand and differs slightly from understanding store choice in terms of "how consumers truly experience competition - as reflected in the choices they feel they have" (see Clarke et al., 2006, 23). Quantifying store gravity is an approach that underpins spatial interaction modelling and has been subsequently employed in location planning and site research departments across a wide range of food retailers and typically provides accurate forecasts if implemented appropriately (Birkin et al., 2010; Reynolds and Wood, 2010; Wood and Reynolds, 2012a) (see Table 2 that identifies variables affecting store performance).

Table 2 about here

With greater competition that is characteristic of conditions approaching saturation, impacts from proximate stores (both owned and from competitors) are increasingly common. As Zhu et al. (2009) underline, the specific effect of the arrival of a competitor within a catchment depends on its particular size, fascia, retail brand and subsequent gravity in relation to the retailer $(s)$ it is competing against. Therefore, such effects are derived from the specific interrelationships between the retailers concerned as well as local factors (including the age and condition of the store). Within such contexts, retailers are set the task of increasing their attractiveness or gravity to defend against the impact. Most obviously - and traditionally considered within the academic literature - is the effect of a new store opening from a competitor, but also, store rebranding, a change of owner, or simple refurbishment of a unit may positively affect a store's attractiveness and are important elements of portfolio management that are often under-emphasized (Bennison et al., 1995). As noted earlier, store extensions have also been a significant channel of store expansion and remain characteristic of the development programmes of the leading retailers - something that has been transformative in nature when converting a superstore to a hypermarket format. Finally, retailers are continually refitting and refreshing their current portfolios to improve the store environment and customer experience. We examine these responses in turn - particularly focusing on the nature of impacts and cannibalisation that occur at the local catchment level.

\footnotetext{
${ }^{3}$ Cadwallader (1975) makes the distinction between actual measured distance and the consumer's cognitive distance ('a measure of how far an individual thinks two places are apart', p 340) in partly governing consumer behaviour.
} 
In the first instance, where a new store opens and its trading catchment partly overlaps with that of an existing competitor, Figure 6 identifies a simplistic shaded "battleground" where the two operators vie for market share and are likely to allocate local marketing spend in an effort to increase market penetration (Wood and Reynolds, 2012b).

Figure 6 about here

After the store has been open for a number of years, competitive responses to improve its attractiveness are common. For example, a store refit upgrades store conditions, layout and appearance, often with slight amendments in ranging, but falls short of fundamentally changing the size of the trading area (Wrigley, 1998). As former Tesco Chief Executive, Terry Leahy $(2012,36)$, simply put it, "refurbishment programmes are essential: stores age so quickly that if you do not remodel or refresh them, they quickly lose custom, undermine customer loyalty and become a drain on the company. Delay costs money". The enhancement of the leading retailers' existing portfolios is critical to understanding retail provision in relation to demand - one must not simply consider new store development. To take the example of one leading food retailer, in 2011/12, J Sainsbury dedicated $£ 1.07$ billion of capital expenditure on development of its store portfolio split between new store development $(£ 599 \mathrm{~m}-56 \%)$ and extensions and refurbishments $(£ 478 \mathrm{~m}-45 \%)(\mathrm{J}$ Sainsbury, 2012).

Figure 7 depicts Store B as undergoing such an improvement in store offer and thus increases its catchment area, into that previously enjoyed by Store A. Of course the inverse of this scenario may occur in the event of a competitor performing very poorly. For example, Morrisons struggled to integrate the Safeway portfolio of stores following its acquisition in 2004 as store standards and availability deteriorated which, in turn, provided an attractive trading environment within numerous catchments for Tesco, Sainsbury's and ASDA Walmart - something that has since been rectified (Findlay and Sparks, 2008). Indeed, Tesco, until relatively recently, had enjoyed "soft" competition with Morrisons pre-occupied with merger integration and Sainsbury's experiencing issues with on-shelf availability (prior to the arrival of current CEO, Justin King) (cf. McKinnon et al., 2007). Recent market share and store switching data suggests that these competitors have improved their product and store propositions and been affecting Tesco in the manner described in Figure 7. 
Store extensions. We earlier noted the manner in which extending an existing store can add floorspace in an already established location. The effect of a modest extension on a store, for example of 10,000 sq ft, is presented in hypothetical form in Figure 8. In this diagram, the original catchment is displayed in the inner curve and exhibits market penetration rates in relation to drivetime - so at point $\mathrm{A}$ for example, the market penetration rate is $40 \%{ }^{4}$ where customers have to travel 8 minutes to the store. In this idealised scenario, no significant competition is assumed so the store's catchment effectively extends to a 15 minute drivetime but logically exhibits a deteriorating market penetration with distance.

The second dashed line represents the change in the catchment that accompanies the hypothetical addition of a modest extension of circa 10,000 sq $\mathrm{ft}$ to a superstore. This enhances the attractiveness of the store but falls short of the transformative effect of a larger extension. Consequently, the market penetration rate intensifies within the current catchment of the store and therefore sales increase, but crucially the store is unlikely to significantly extend its catchment beyond 15 minutes.

Figure 8 about here

Earlier we noted how leading retailers have frequently pursued major extensions that fundamentally change store attractiveness by providing additional space to a strongly performing superstore, characterised by high sales densities ( $£$ per sq ft). This has often seen the trading space allocated to food increase to around $40,000 \mathrm{sq} f \mathrm{ft}$ in order to relieve trading pressure, with the majority of the space increase providing an extensive non-food/general merchandise product offer. Indeed, Hallsworth et al. (2010), cite the Competition Commission $(2009,23)$ which suggested that: "60 per cent of the space added by extensions across the industry over 2000 to 2006 was to enhance non-food retailing". Figure 9 represents the impact of the increased attractiveness at a local catchment level. While the extension leads to additional market penetration within the store's existing catchment, the additional space and associated product offer provides a step-change in the geographical reach of the store to customers located further away. In simple terms, customers become prepared to travel further to reach a (now) "destination store" AND the market penetration increases within its existing catchment. Importantly, the additional space provides new sales (primarily from non-food due to the likely nature of the extra space) but also the additional

\footnotetext{
${ }^{4}$ In other words, $40 \%$ of all sales available at this location are captured by the store.
} 
customers that are attracted to the store will also conduct a food shop: the non-extended food space will effectively benefit from a "halo" with the extension. Importantly this means that with transformative extensions there have been greater impacts on competitors' like-for-like sales - but also potentially self-impacts/sales cannibalisation, given the larger stores and wider catchments. As we have noted earlier, recent returns from non-food space within hypermarkets have deteriorated so the continued success of this strategy is questionable, but its discussion here is important to understanding the conditions that have led to the current conditions within the market.

Figure 9 about here

New format development - convenience stores But what about the dynamics of store-onstore interaction with the development of new retail formats? It is well-known that the leading food retailers have aggressively entered the convenience store market - partly due to the need to adapt to the demands of an increasingly working population that require locational convenience, but also due the restrictive land-use planning policies that have limited the availability of desirable out-of-town sites for larger store formats (Wrigley et al., 2009). As Clarke et al. $(2012,1897)$ summarise, "the combined effect of the out-of-town dominance of multiple retailers combined with these new in-town corporate convenience stores has resulted in a significant increase in local brand concentration".

As the Competition Commission (2006) notes, convenience stores primarily fulfil a top-up or secondary shopping mission, while the larger superstore and hypermarket formats cater to the primary shopping task. To some degree therefore, the two formats are complementary in their focus - something that supports the assertion that format innovation can partially delay the onset of saturation. However, it is likely that such formats have contributed to the cannibalisation of sales especially if such stores are located within the catchment of existing superstores and hypermarkets - while the customer shopping missions may often be different between the two stores, they still sell food with the subsequent reduction in product choice possibly aiding consumer decision-making (cf. Ashkenas, 2009). Figure 10 displays the catchment for a superstore $(\mathrm{S})$ and a convenience store $(\mathrm{C})$ with a $£ 5$ spend. In this instance, the two stores do not directly compete, nor do they directly compete in the superstore’s $£ 100$ wider catchment (the outer circle). However, convenience stores can still cause cannibalisation by consumers channelling their expenditure to proximate small stores from superstores or hypermarkets to save time, travel costs or cut expenditure. It is a 
problem even if customers are loyal to the retailer brand - with visits to corporate convenience store fascias providing access to the supermarket brand and product quality. In the process, there is a strong likelihood of overall reduced customer expenditure given the vastly reduced range and promotional offers available at a 3,000 sq ft convenience store visà-vis a superstore $(25,000-60,000 \mathrm{sq} f t)$ or larger hypermarket $(60,000 \mathrm{sq} \mathrm{ft}+)$. This is something extremely important to understand for retailers such as Tesco and Sainsbury that have a UK convenience store portfolio of 2,186 (including the One Stop fascia) and 440 respectively.

Figure 10 about here

Such analysis suggests that superstores cannot be separated in any meaningful sense from convenience stores in considering the dynamics of food retail catchments. This view is supported by the little amount of modelling research that has compared inter- and intraformat interaction. Notably, while González-Benito et al. (2005) find that customers tend to adopt a "two-step hierarchy in the process of retail store choice in which the consumer chooses first the type of store in which to shop and second, the specific store within that format", they also observe inter-format interaction and cross shopping. They conclude: "spatial analysis should not focus exclusively on a specific store format. Although intraformat competitive interaction is more intense, the consequences of inter-format rivalry should not be dismissed" ( $p$ 69). The store choice decision is therefore partly a function of spatial convenience as well as a judgement regarding the specific format. It is also dependent on the geodemographic make-up of the consumer. In a later study, González-Benito et al. (2007) find that the attractiveness of a store format is particularly related to particular lifestages and incomes. Such research underlines that although store formats may appear distinct and have differential cross-shopping/competitiveness relationships between them, they are certainly not wholly separate in terms of target segments and therefore affect each other to varying degrees (González-Benito, 2005). In short, therefore, the development of sizeable portfolios of small stores by the leading retailers impact conventional food stores and ultimately contribute to saturation. However, in regulatory terms, they remain distinct markets - namely the retail market for "one-stop shopping" (hypermarkets, superstores, supermarkets) and the retail market for "secondary shopping" (convenience stores) (Competition Commission, 2006). 
Cannibalisation and self-impacts. It is important to distinguish between sales impacts at the local level from retail competition trading proximate to an existing store and effectively "selfimpacts" or sales cannibalisation from surrounding stores also owned by the retailer concerned (Dibb and Simkin, 1994). The latter is especially concerning for large retailers given their extensive store estates where store catchments clearly intersect: Figure 11 shows an existing Store A and a new Store B, along with a Customer X. While both stores are situated within the customer's 15 minute drivetime, the new Store B is closer to the customer ( 8 minute drivetime) than the existing Store A (12 minute drivetime). We present three scenarios to underline why cannibalisation potentially provides a greater impact than a competitor impact.

$\underline{\text { Scenario 1: }}$ if Store B is a competitor store and Customer X is indifferent, it is logical that s/he will move from shopping at Store A to Store B, leading to a deterioration in Store A's like-for-like sales performance.

$\underline{\text { Scenario 2: }}$ if Store B is once again a competitor, but this time Customer $\mathrm{X}$ is loyal to Store A, s/he will trade off the additional 4 minute drivetime for what $\mathrm{s} /$ he regards as a better offer, store quality etc. Indeed, strong retail brands are known to foster such loyalty (Burt and Sparks, 2002; 2003) and therefore suffer smaller impacts and - conversely - produce larger impacts on competition when they open.

$\underline{\text { Scenario 3: }}$ if Store B is the same retailer as Store A and Customer X is loyal to the store brand, it is logical behaviour for him/her to switch to the closer and newly opened Store B, thereby remaining loyal to the brand. Store A's like-for-like sales performance is affected likely severely - given that Customer $\mathrm{X}$ is a loyal and presumably high spending consumer. Clearly therefore cannibalisation has a greater impact than a competitor impact. Understandably retailers may argue that they retain sales in such a scenario, rather than lose them to a competitor. However, if this situation is repeated across the business, aggregate store portfolio like-for-like sales performance suffers with much more costly retail space to operate that is also significantly less productive. Therefore, the more the leading food retailers grow and the larger the stores become, the more impacts they will inflict on each other and the greater propensity for them to suffer from cannibalisation. 


\section{Future food store development: Industry versus firm level competitive motivations}

So far we have examined why slowing the level of capital investment in new store development makes sense at the macro-industry level. However, it is prudent to question whether such a change in strategy actually makes sense at the level of the individual retail firms in the context of likely competitor responses. We argue that continuing to open new space may be rational for individual retailers, but irrational for the industry overall. As Clarke et al. $(1994,13)$ note, the dilemma for retailers is "that to realize market potential they have to invest in constructing outlets, but in doing so they must recognize that they cannot control future competitive actions". In the case of retail location strategy in the early 1980s, Ghosh and Craig (1983, 58-9) allude to such a scenario:

\footnotetext{
"Since the retailers are competing directly in the same market, the actions of any one retailer have direct repercussions on the profitability of other retailers. Moreover, since the total market potential for the entire planning horizon is fixed, the strategic choice process is similar to a zero-sum, noncooperative game between the retailers. When a competitor's reaction to a particular strategic choice is unknown, a firm evaluates any strategy in terms of the worst case scenario - the pay-off the firm would receive if competition chose the best reactive strategy. Thus, facing uncertainty about the competitor's likely reaction, it is rational for a firm to choose the strategy that maximizes the minimum possible pay-off".
}

Such incentives mean that the firm is likely to adopt a path that protects its interests and market position from future competitive changes. To simplistically illustrate this point, let us consider what a rational strategy would be for two retailers acting independently in a hypothetical closed system scenario of two equally-sized towns, 1 and 2, and two retailers, A and B: with Retailer A taking 100\% share in Town 1 and Retailer B taking 100\% share in Town 2 (see Figure 12). If Retailer A decides to expand and opens in Town 2 and takes 50\% share in that town, it now has $100 \%$ share in Town 1 and 50\% share in Town 2 . The response of Retailer B would logically be to open in Town 1, and take $50 \%$ share of that town. Consequently, each retailer would attain $50 \%$ share in each town - something that has happened as the capital invested has doubled as each retailer has expanded, while their total sales remain unchanged - it is just that $50 \%$ of sales come from two separate towns, rather than each having a monopoly in a single town. Profits and returns have fallen. While admittedly there may have been some market growth, it would not have doubled in line with 
the retailers' expansion, so there is little debate that returns deteriorate and the viability of such stores likely becomes marginal.

Figure 12 about here

However, if Retailer A did not expand, it would still have been logical for Retailer B to expand and take $50 \%$ of Town 1. This would then force Retailer A to open in Town 2 and we end up with the same outcome by a different route. Essentially, whatever Retailer A does (expand or not expand), it is rational for Retailer B to expand, irrespective of what A does, and vice versa. The decision to expand is independent of the other retailer's choice. The conclusion though is an irrational outcome for the collective industry. Companies act in their own self-interest and not in the interest of the industry. Therefore, as Ghosh and Craig $(1983,66)$ conclude specifically in the context of retail network planning, "The possibility of competitive reactions and changes in the marketing environment adds additional dimensions to retail location strategy. In a dynamic retail environment a firm must take into account the state of the entire system not only in its present condition but also as it will be in the future".

If we consider the current situation within UK food retailing, at first sight Tesco's rationale for slowing their store development appears logical and focused on securing current rather than developing new customers: "New stores are about new customers, not loving the customers we've got... taking care of the customers you have is the best way to attract the customers you don't" (Clarke, 2012). However, in the past Tesco has outmanoeuvred the competition in a period of slower store development. For example, in the early 1990s, ASDA management convinced investors that the industry was mature and that openings should be curtailed. Investors put pressure on the retailers and consequently all the major food retailers issued statements indicating they were cutting their opening programmes. However, Tesco "cheated" in game theory terms by returning to the market and buying a large number of sites at low prices (given the lower competition for sites). It is important to note that at this time, the ability of ASDA to respond in line was hampered by considerable financial pressure, prior to its acquisition by Walmart (Sparks, 2011). In the process, Tesco not only developed conventional superstore sites, but also secured a presence in "smaller catchments, for example small market towns with an extensive rural hinterland, with smaller food-only stores of around 2,000-3,000 sq m" (Guy, 2007, 68). Consequently, Tesco outmanoeuvred the competition and secured significant long run first mover advantages. 
Given this relatively recent history, it is highly unlikely that the leading food retailers will be exploited in the same manner again. There are low levels of inter-firm trust within the sector and we speculate that retailers are prepared to send misleading information to competitors. Importantly, it is clearly in Tesco's interest to slow the expansion given the likely degrees of cannibalisation it is experiencing (despite its suggestions to the contrary) so it should not be surprising that it has led the industry in slowing its development programme. Similarly, Sainsbury's opening programme is likely to be adding only marginal value (postimpacts). In contrast, retailers such as ASDA Walmart, Waitrose and the discounters, such as Aldi, have motivations to keep expanding given their incomplete store geographies and relatively low levels of self-impacts.

\section{Conclusions and implications}

In the light of the apparent slowdown in store development in the UK food retail market, we have provided a conceptual review of the dynamics of store expansion at a catchment level and explored the manner in which different types of development impacts can lead to saturation. This has emphasized the essentially local fascia and format-specific nature of retail market saturation, leading to a number of conclusions:

First, our conceptual analysis has underlined the heterogeneous nature of retail competition and saturation across space. As such, any suggestions that the aggregate UK market is currently in a saturated condition are largely unhelpful. Retail saturation will be experienced differently for different retailers with different formats and brands across different catchments - something that suggests indexes of aggregate space per capita/household are limited in the their explanatory capabilities ( $c f$. Langston et al., 1998). Recent research suggests that there remain considerable expansion opportunities for targeted operators, such as the hard discounter, Aldi, in the UK (Thompson et al., 2012), meanwhile larger, established operations such as Morrisons continue to expand aggressively particularly in the south of England where it is under-represented through its food-focused store formats. In contrast, regulatory change - such as the proposed Competition Test - may further restrict the expansion possibilities of market leader, Tesco, therefore bringing saturation closer for this particular operator (Hughes et al., 2009). Saturation will not be a phenomenon that affects all retailers everywhere at the same time but is likely to become an increasingly evident trend as investments in new store space (and returns on existing space) become increasingly marginal. 
Second, linked with this, the paper illustrates how retail saturation is an interdependent concept as each company's saturation level is partly a function of its competitors' relative strength. In short, Tesco's saturation point is coming closer given Morrisons, ASDA Walmart and Sainsbury's recent stronger performance over the past five years. However, there remain catchments where there is adequate potential for significant development still to occur and of course the food retailers have considerable development programmes going forward, even if they are no longer at the levels experienced between 2006-2012.

Third, the paper has underlined the importance of the retail format and retail channels to understanding retail saturation. Clearly, much of the recent concern has stemmed from the relative underperformance of the hypermarket format, partly due to predation from online retailing - something which offers considerable future research opportunities to better conceptualize the linkages between the hypermarket (with its extensive general merchandise offer) and online sales channels ( $c f$. Weltevreden and van Rietbergen, 2009). More broadly, considerable work remains still to do in fully untangling the relationship between food retailer stores and their online operations - because, as the Financial Times (2013b) puts it, "retailers struggle to account for sales channels". While the online threat to hypermarkets' general merchandise offer is well-known, the predominant store-based fulfilment of online food orders positions physical stores as central to retailers' virtual store operations (Fernie et al., 2010). In addition, the potential for click \& collect services also underlines the benefit of extensive store estates, as CB Richard Ellis $(2012 b, 2)$ note:

"Whatever the problems UK operators are currently experiencing in creating European style hypermarket offers, the locational dominance of grocery networks looks set to keep grocery operators at the cutting-edge of multi-channel development."

Quite where these sales are attributed (to the stores themselves or a separate "online" division) will affect perceptions of profitability of both channels. In short, we need to understand the online cost model and its relationship to stores in greater depth - to what degree is one subsidising the other? In addition, we have suggested that retail innovation of store formats and ranging propositions often provides opportunities for further portfolio development and may delay the arrival of retail saturation. Importantly though, to regard new formats as mutually exclusive and not contributing to saturation is erroneous - as the discussion of convenience catchments in relation to superstores indicates. 
Fourth, our analysis has considered retail competitive interaction in relation to store development and underlined how seemingly irrational development strategies at the industry level may make sense at the level of the individual retail firm. This suggests that there is likely to be a divergence between retailer public pronouncements concerning store development pipelines and their actual site acquisition and construction activities.

Finally, while it is understandable that there has been a keen focus on store development over the period 2006-2012, given the long term advantages that accrue with sunk cost in strategic store locations which are defendable in the face of subsequent store development, recent experiences have underlined the drawbacks of a "desperation to satisfy investors with new store growth" (Joseph and Kuby, 2013, 158). There is evidently a need to reconcile expansion with the maintenance of capital investment in store operations to sustain levels of customer experience and service across the portfolio, as well as in physical store appearance. Such investment maintains a store's attractiveness and limits impacts from competitor openings - something that we have seen will become increasingly inevitable. 


\section{Tables and Figures}

Figure 1: UK Total Grocery Outlet Pipeline, 2002-2013

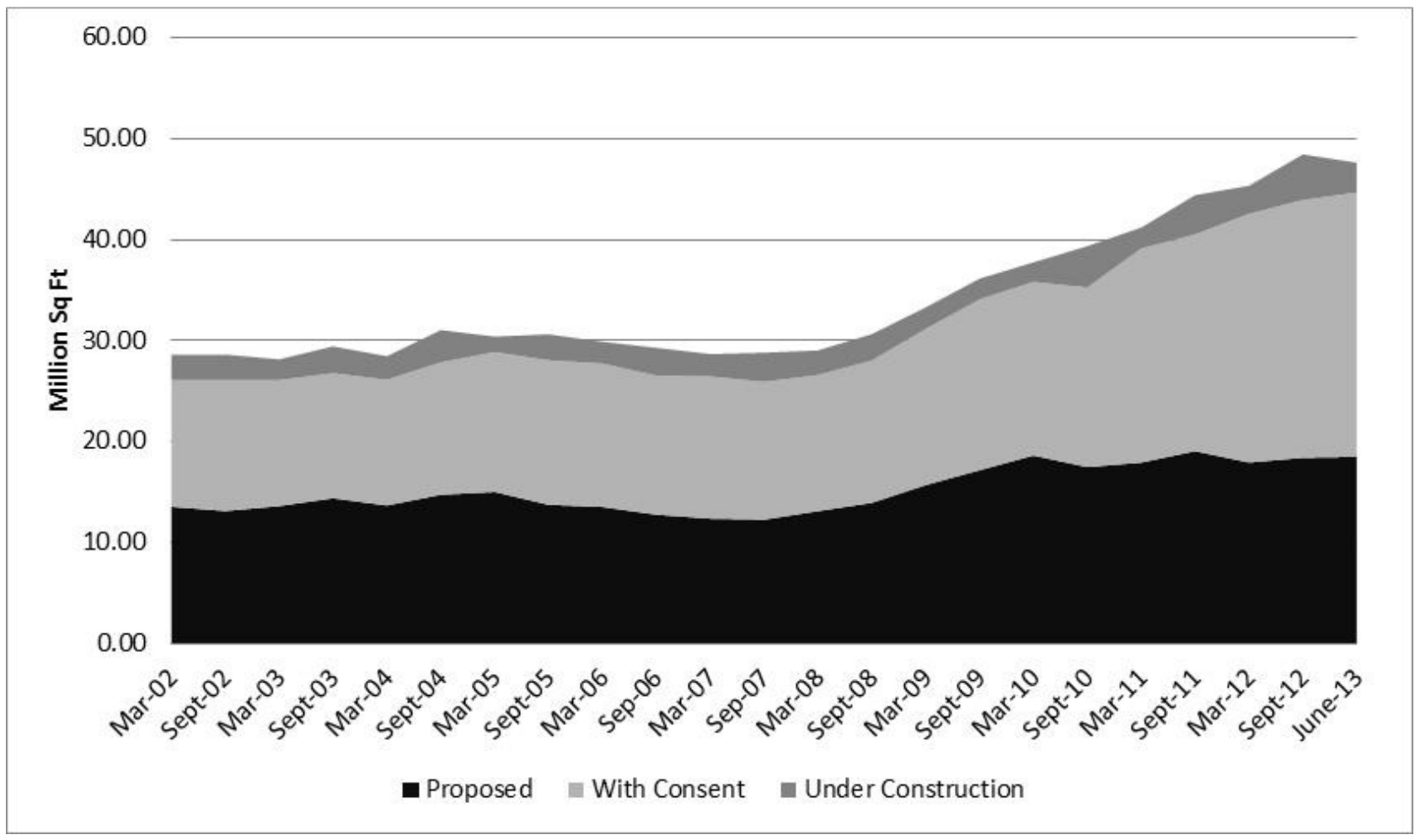

Source: CB Richard Ellis (2013) 
Figure 2: Tesco Extra Format Store Numbers and \% of Extra Format Space Increase Per Year Due to Extensions From Superstore Format

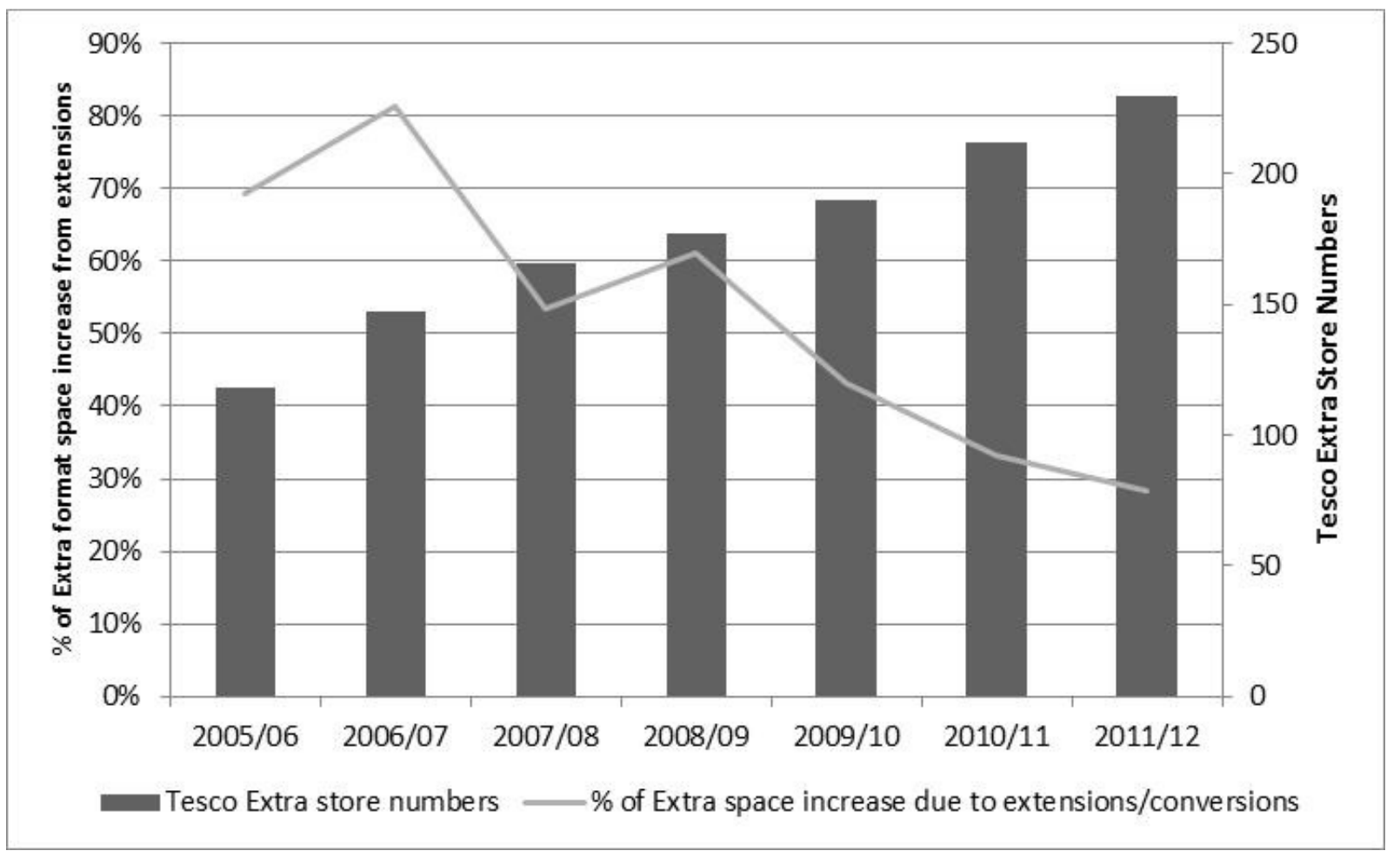

Source: Tesco analyst packs 2000-2012 
Figure 3: UK Grocery Outlets Under Construction, 2002-2013

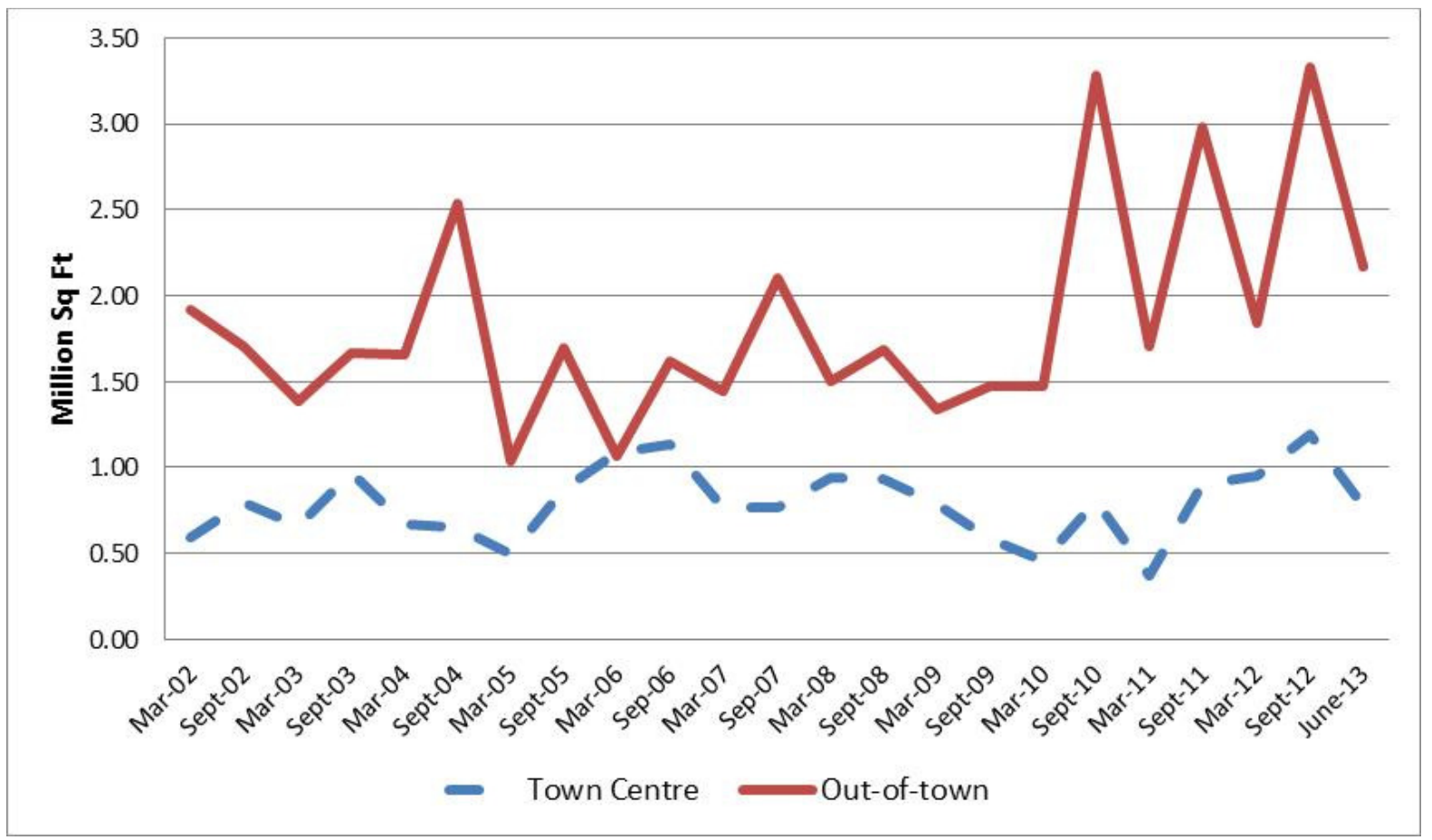

Source: CB Richard Ellis (2013) 
Table 1: Big 4 Food Retailer openings - net space ('000 sq ft - FY 2007-2012)

\begin{tabular}{|l|l|l|l|l|l|l|}
\hline Company & $\mathbf{2 0 0 7}$ & $\mathbf{2 0 0 8}$ & $\mathbf{2 0 0 9}$ & $\mathbf{2 0 1 0}$ & $\mathbf{2 0 1 1}$ & $\mathbf{2 0 1 2 e}$ \\
\hline Tesco & 1,737 & 1,670 & 1,597 & 1,560 & 2,156 & 2,000 \\
\hline Sainsbury's & 578 & 486 & 512 & 1,047 & 1,330 & 1,150 \\
\hline Morrisons & -128 & 332 & 294 & 736 & 400 & 500 \\
\hline ASDA & 706 & 610 & 683 & 493 & 475 & 800 \\
\hline Total & $\mathbf{2 , 8 9 3}$ & $\mathbf{3 , 0 9 8}$ & $\mathbf{3 , 0 8 6}$ & $\mathbf{3 , 8 3 6}$ & $\mathbf{4 , 3 6 1}$ & $\mathbf{4 , 4 5 0}$ \\
\hline
\end{tabular}

Source: Estimates from Evolution Securities

Figure 4: Tesco, ASDA Walmart and Sainsbury's Hypermarket Sales Densities, 2007 2016e

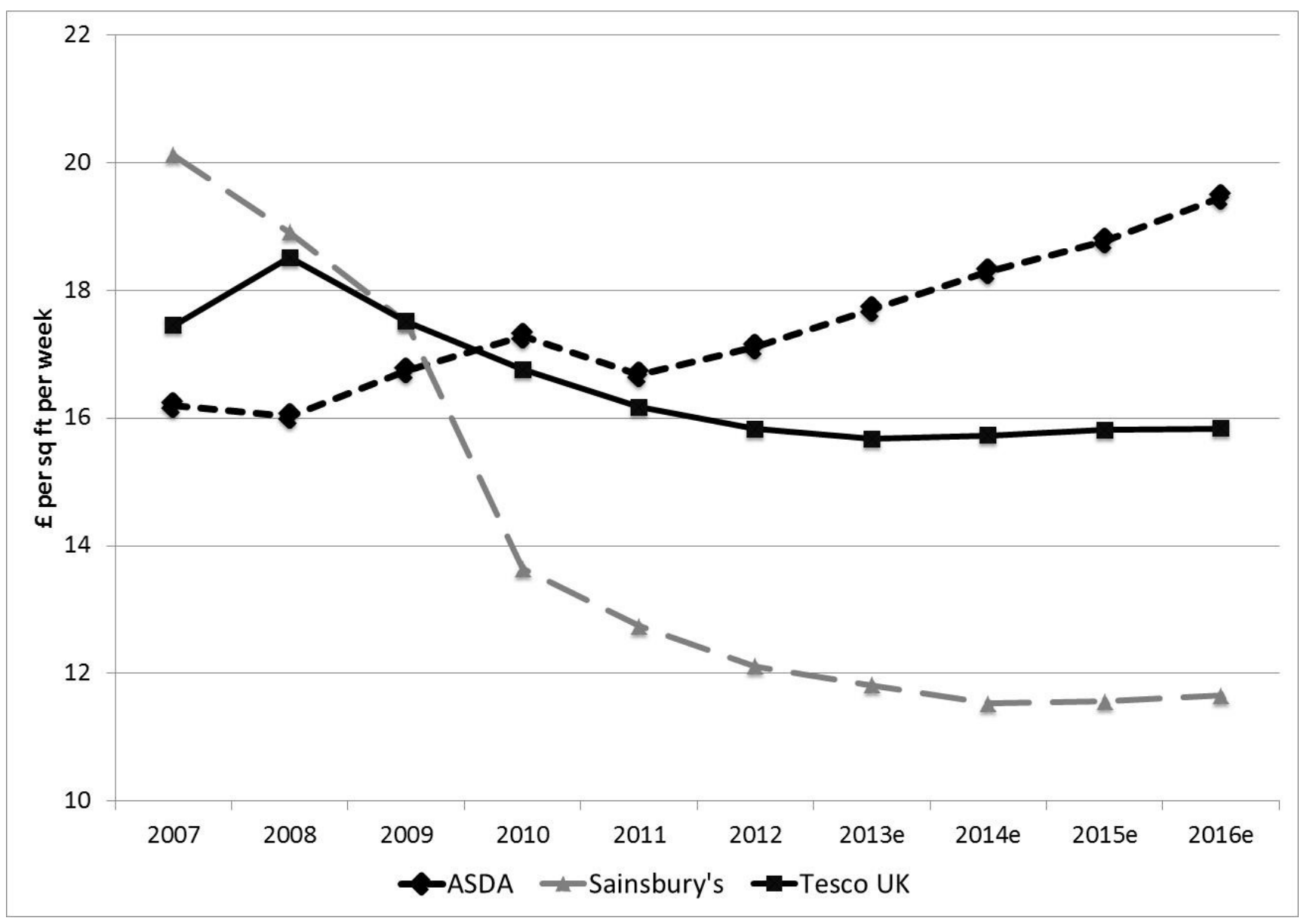

Source: data obtained from IGD Datacentre (2013) 
Figure 5: "Big 4" UK Food Retailers' Overall Sales Densities, 2007 - 2016e

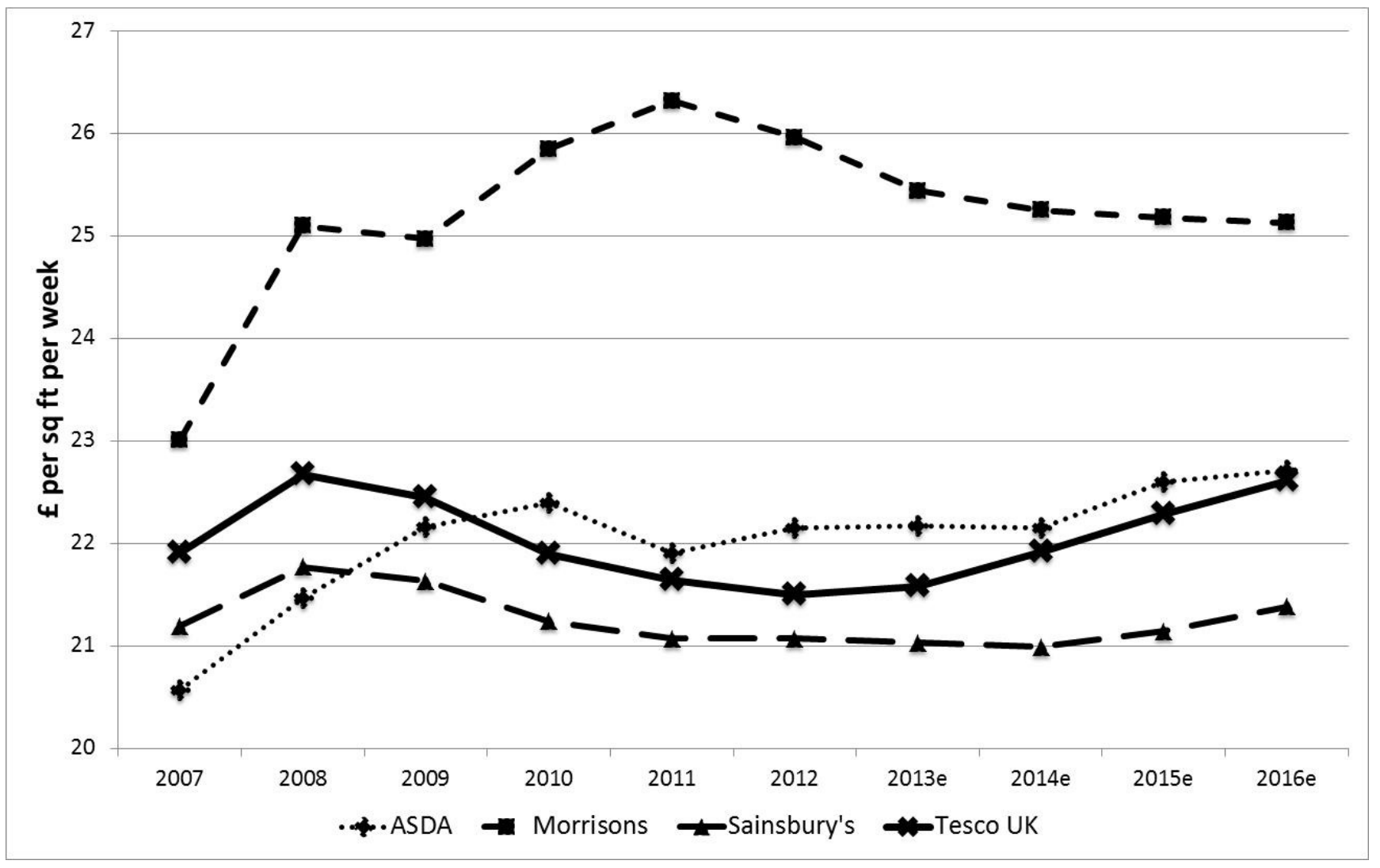

Source: data obtained from IGD Datacentre (2013)

Table 2: Key variables affecting store performance

\begin{tabular}{|l|l|}
\hline Store brand & Derived from the corporate brand, store image, positioning \\
\hline Store attraction & $\begin{array}{l}\text { A function of the store size, product range, positioning, facilities (e.g. petrol } \\
\text { station), access \& egress }\end{array}$ \\
\hline Local population & $\begin{array}{l}\text { The size and characteristics of the local population and its location in } \\
\text { relation to store and its competition. }\end{array}$ \\
\hline Road network & Accessibility of the store to the population \\
\hline Competition & $\begin{array}{l}\text { Characteristics of the store competition - brand, store size, range, facilities, } \\
\text { location in relation to current/proposed unit }\end{array}$ \\
\hline
\end{tabular}

Source: Current study; Roig-Tierno et al. (2013); Wood and Reynolds (2011) 
Figure 6: New store - competitor impact

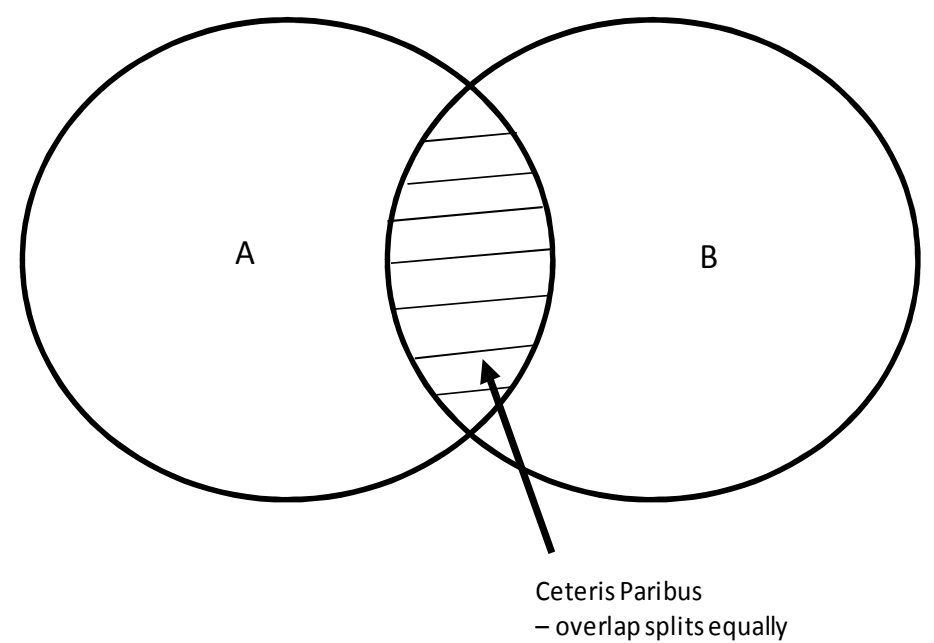

NB: This figure provides a simplified completely circular catchment around the two stores. Obviously given the differential efficacy of transport routes over space, market penetration and purpose of visit, such catchments in reality are irregular in shape (see Dennis et al., 2002).

Figure 7: Store B improves its attractiveness/gravity

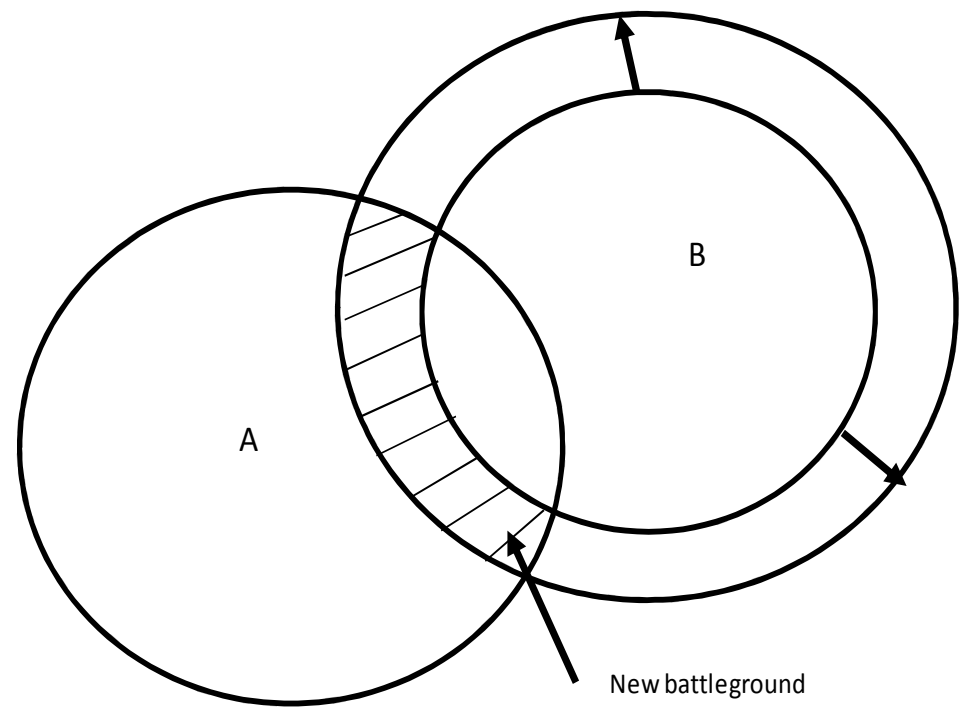


Figure 8: The change in catchment due to a small extension

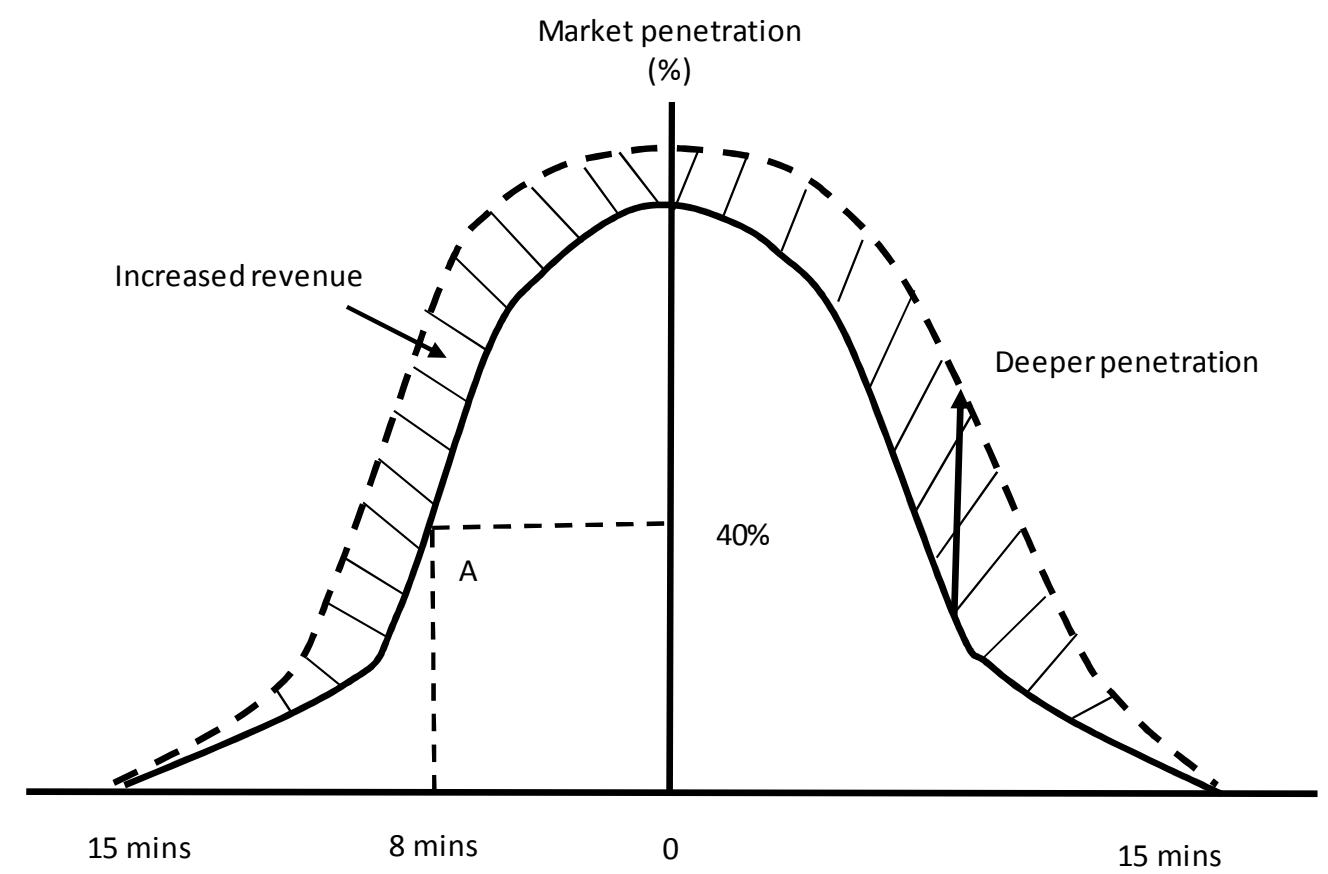

Figure 9: Increase in store catchment from a transformational extension (e.g. from superstore to hypermarket format)

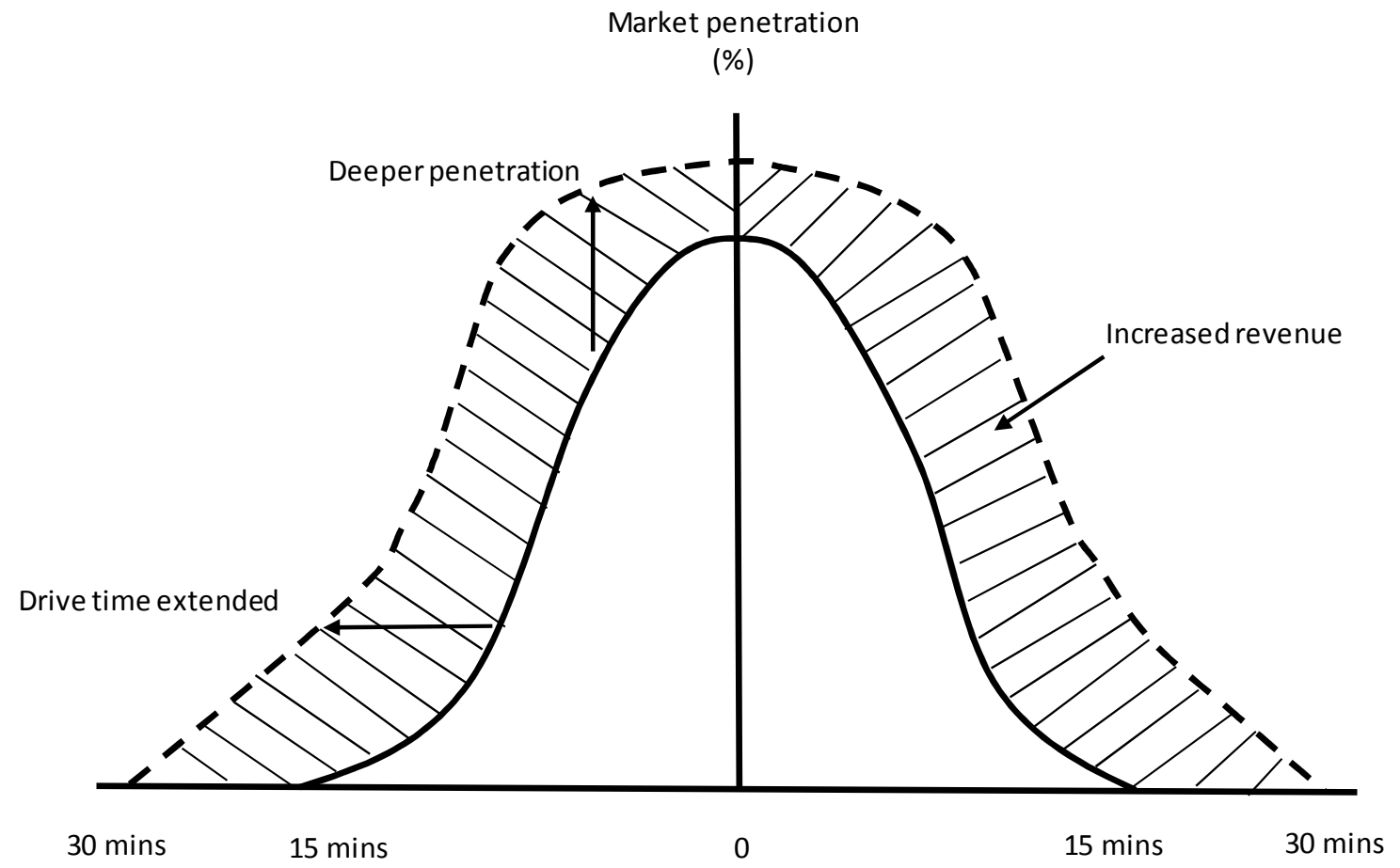


Figure 10: Convenience catchments

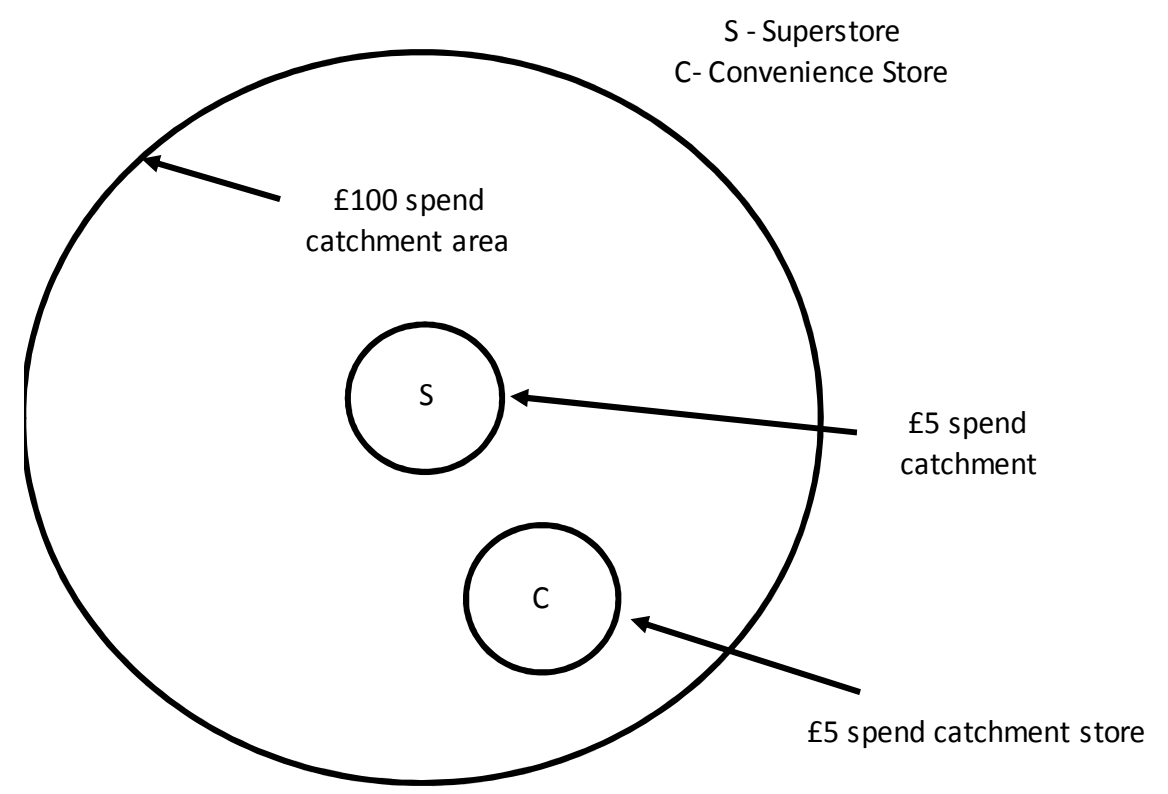

Figure 11: Loyalty and cannibalisation

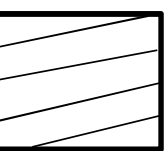

Battleground

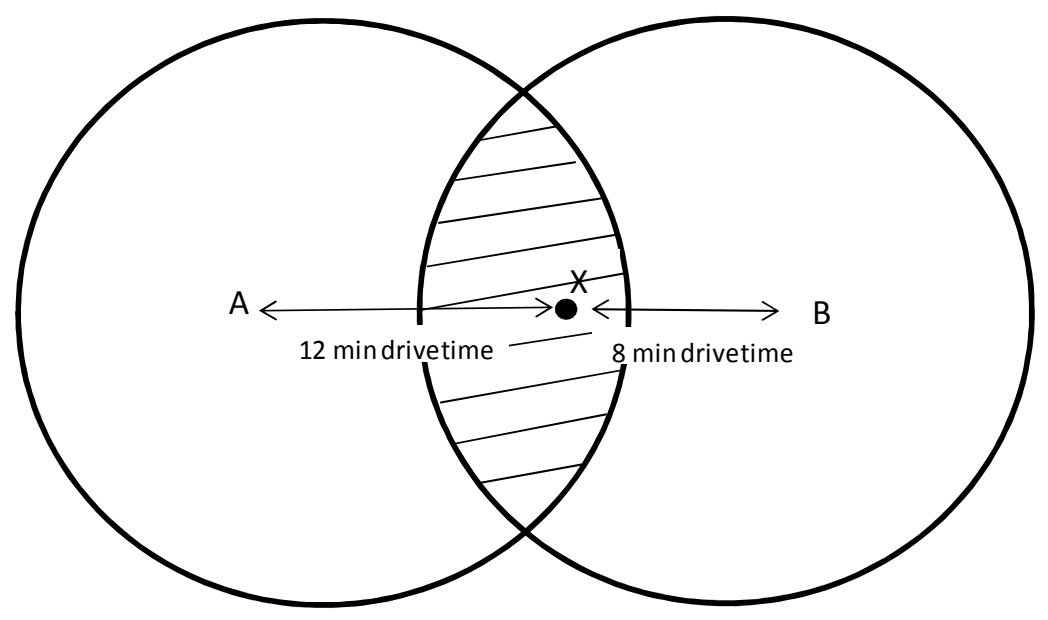


Figure 12: Industry versus retailer level expansion imperatives

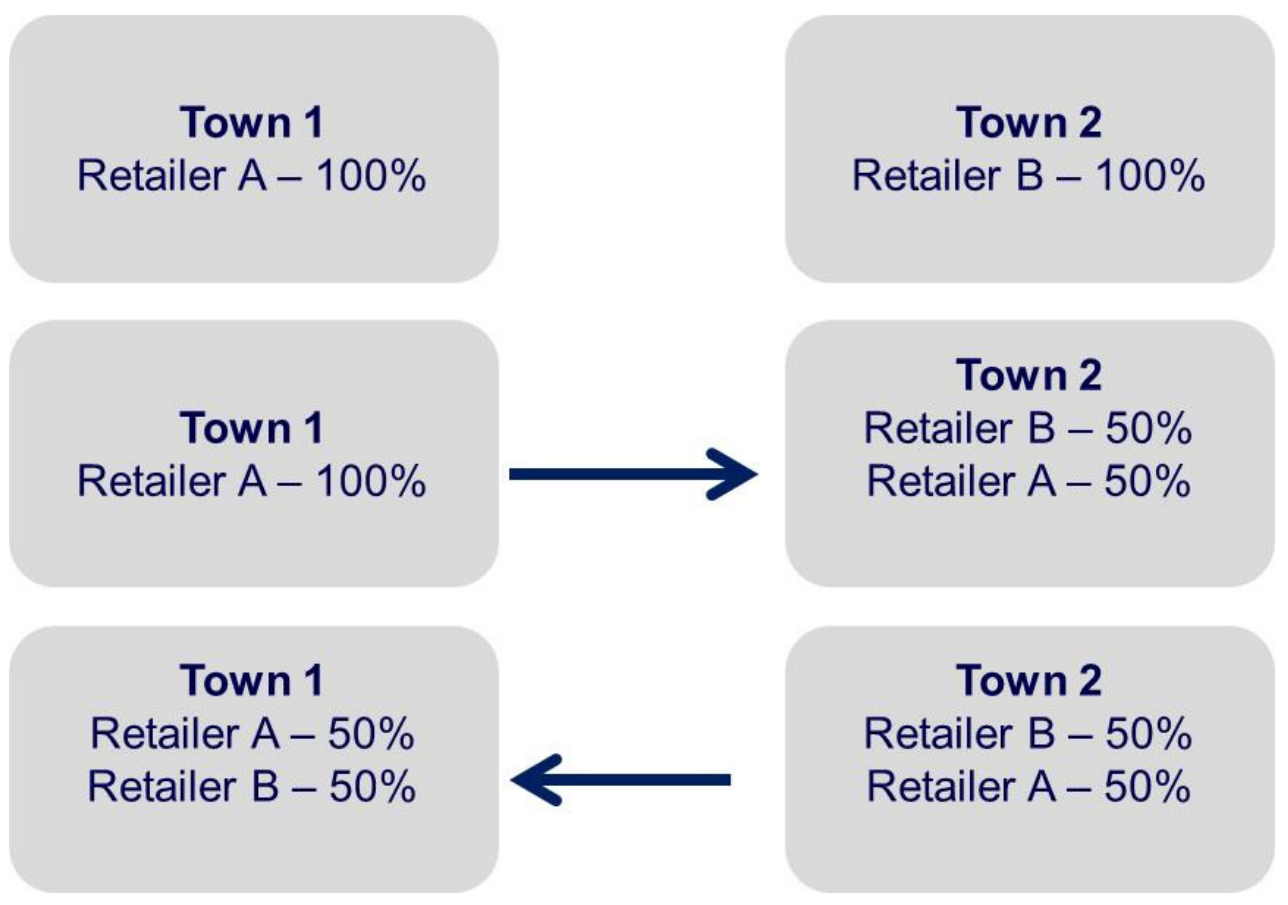

\section{References}

Alexander, N., and W. Morlock. 1992. "Saturation and internationalization: the future of grocery retailing in the UK." International Journal of Retail \& Distribution Management 20 (3):33-39.

Ashkenas, R. 2009. "Restrict My Choices, Please", HBR Blog Network. Accessed at http://blogs.hbr.org/cs/2009/12/restrict_my_choices_please.html\#disqus_thread

Barclay. C. 2012. Town centres, Planning and Supermarkets, House of Commons Library Standard Note: SN/SC/1106. Accessible at http://www.parliament.uk/briefingpapers/SN01106

Bennison, D., I. Clarke, and J. Pal. 1995. "Locational decision making in retailing: an exploratory framework for analysis." International Review of Retail, Distribution \& Consumer Research 5 (1):1-20.

Birkin, M., G. Clarke, M. Clarke. 2002. Retail Geography \& Intelligent Network Planning. Chichester: John Wiley \& Sons.

Birkin, M., G. Clarke, M. Clarke. 2010. "Refining and operationalizing entropy-maximizing models for business applications." Geographical Analysis 42: 422-445.

Burt, S., and L. Sparks. 1994. "Structural change in grocery retailing in Great Britain: a discount reorientation?" The International Review of Retail, Distribution and Consumer Research 4:195-217. 
Burt, S. L. and L. Sparks. 2002. "Corporate branding, retailing, and retail internationalization." Corporate Reputation Review 5: 194-212.

Burt, S. L. and L. Sparks. 2003. "Power and competition in the UK retail grocery market." British Journal of Management 14: 237-254.

Cadwallader, M. 1975. "A behavioral model of consumer spatial decision making" Economic Geography 51: 339-349.

Castrillo, J., P. Gurdjian and R. Mira. 1998. "Have hypermarkets had their day?" McKinsey Quarterly 4: 80-87

Cheshire, P., C. A. L. Hilber and I. Kaplanis.2011. Evaluating the Effects of Planning Policies on the Retail Sector: Or Do Town Centre First Policies Deliver the Goods? SERC Discussion Papers, 66, Spatial Economics Research Centre, London School of Economics and Political Science.

Clarke I, D. Bennison and C. Guy. 1994. "The dynamics of UK grocery retailing at the local scale" International Journal of Retail \& Distribution Management 22: 11-20

Clarke I, A. Hallsworth, P. Jackson, R. de Kervenoael, R. P. del Aguila and M. Kirkup. 2006. "Retail restructuring and consumer choice 1. Long-term local changes in consumer behaviour: Portsmouth, 1980-2002" Environment and Planning A 38: 25-46

Clarke I, M. Kirkup, and H. Oppewal. 2012. "Consumer satisfaction with local retail diversity in the UK: effects of supermarket access, brand variety, and social deprivation" Environment and Planning A 44: 1896-1911

Clarke, P. 2012. Winning customers in a world of change, Talking Tesco Blog, 19 September 2012. Accessed at http://www.tescoplc.com/talkingshop/index.asp?blogid=54

Competition Commission. 2006. Grocery Market: Proposed Decision to Make a Market Investigation Reference. March 2006. Office of Fair Trading, HMSO.

Competition Commission. 2008. The Supply of Groceries in the UK Market Investigation. April 2008. Office of Fair Trading, HMSO.

Competition Commission. 2009. Remittal Response. http://www.competitioncommission.org.uk

Dawson, J. 2012. "Retailer activity in shaping food choice" Food Quality and Preference, in press doi: http://dx.doi.org/10.1016/j.foodqual.2012.09.012

Dennis, C., D. Marsland, and T. Cockett. 2002. "Central place practice: shopping centre attractiveness measures, hinterland boundaries and the UK retail hierarchy". Journal of Retailing and Consumer Services 9 (4):185-199.

Dibb, S. and L. Simkin. 1994. "Retail store performance model the impact of own-branch 'friendly fire'" International Transactions in Operational Research 1: 479-487 
Duke, R. 1991. "Post-saturation competition in UK grocery retailing" Journal of Marketing Management 7: 63-75

Fernie, J., L. Sparks, and A. C. McKinnon. 2010. "Retail logistics in the UK: past, present and future." International Journal of Retail \& Distribution Management 38 (11/12):894-914.

Financial Times. 2007. "Watchdog eyes Tesco's large land bank". Financial Times, July 10 2007. Accessed at http://www.ft.com/cms/s/0/8a7873fe-2f19-11dc-b9b70000779fd2ac.html\#axzz2NtvJoYWm

Financial Times. 2012a. "Tesco ends era of expansion". Financial Times, April 18, 2012. Accessed at http://www.ft.com/cms/s/0/701e0488-8919-11e1-bed000144feab49a.html\#axzz1yX8I96pk

Financial Times. 2012b. "Sainsbury chief attacks No 10 policy". Financial Times, May 9 2012. Accessed at http://www.ft.com/cms/s/0/5d4d481c-99a1-11e1-8fce00144feabdc0.html\#axzz1ymvRmtId

Financial Times. 2012c. "Tesco reels after first profit alert in 20 years". Financial Times, January 12 2012. Accessed at http://www.ft.com/cms/s/0/1ff03ae2-3cef-11e1-ae07$\underline{00144 \text { feabdc0.html\#axzz1ymvRmtId }}$

Financial Times. 2012d. "Outside the big box". Financial Times, August 23 2012. Accessed at http://www.ft.com/cms/s/0/5e4c0d5e-ed00-11e1-9980-

00144feab49a.html\#axzz2QY5G4EL3

Financial Times. 2012e . "End of space race". Financial Times, January 23 2012. Accessed at http://www.ft.com/cms/s/0/f8c06dde-3df7-11e1-91f3-00144feabdc0.html\#axzz2ToheLMIo

Financial Times. 2013a. "Supermarkets eye revival through co-traders", Financial Times, April 1 2013. Accessed at http://www.ft.com/cms/s/0/22c21a44-9723-11e2-a77c00144feabdc0.html\#axzz2PJGyB4UE

Financial Times. 2013b. "Retailers struggle to account for sales channels". Financial Times, April 28, 2013. Accessed at http://www.ft.com/cms/s/0/1a45289e-aff0-11e2-acf9$\underline{00144 \text { feabdc } 0 . h t m l}$

Findlay, A. and L. Sparks. 2006. The Retail Planning Knowledge Base Briefing Paper 6: Scottish Retail Planning Policy. December 2006, Institute for Retail Studies University of Stirling.

Findlay, A. and L. Sparks. 2008. "“Switched": store-switching behaviours" International Journal of Retail \& Distribution Management 36: 375 - 386.

Findlay, A., and L. Sparks. 2012. "Far from the 'magic of the mall': Retail (change) in 'other places'.” Scottish Geographical Journal 128 (1):24-41.

Ghosh, A., and C. S. Craig. 1983. "Formulating retail location strategy in a changing environment." Journal of Marketing 47 (3):56-68. 
González-Benito, Ó. 2005. "Spatial competitive interaction of retail store formats: modeling proposal and empirical results.” Journal of Business Research 58 (4):457-466.

González-Benito, Ó., P. A. Muñoz-Gallego, and P. K. Kopalle. 2005. “Asymmetric competition in retail store formats: Evaluating inter- and intra-format spatial effects." Journal of Retailing 81 (1):59-73.

González-Benito, Ó., C. Bustos-Reyes, and P. Muñoz-Gallego. 2007. "Isolating the geodemographic characterisation of retail format choice from the effects of spatial convenience." Marketing Letters 18 (1):45-59.

Griffith, R., and H. Harmgart. 2012. "Supermarkets competition in England and planning regulation." The International Review of Retail, Distribution and Consumer Research 22 (1):1-25.

The Guardian 2011. "Supermarkets' plan to build thousands more stores revealed", The Guardian, $21^{\text {st }}$ December 2011.

The Guardian 2012. "Tesco and rivals turn against huge stores as internet shopping takes over". The Guardian, 4 March 2012.

Gustafsson, K., G. Jonson, D. Smith, and L. Sparks. 2009. Retailing Logistics \& Fresh Food Packaging: Managing Change in the Supply Chain. London: Kogan Page.

Guy, C. 1994. “Grocery store saturation: Has it arrived yet?” International Journal of Retail \& Distribution Management 22 (1):3-11.

Guy, C. 1995. "Retail store development at the margin." Journal of Retailing and Consumer Services 2 (1):25-32.

Guy, C. 1996. "Grocery store saturation in the UK - the continuing debate." International Journal of Retail \& Distribution Management 24 (6):3-10.

Guy, C. 1999. "Exit strategies and sunk costs: the implications for multiple retailers." International Journal of Retail \& Distribution Management 27 (6/7):237-245.

Guy, C. 2007. Planning for Retail Development. London: Routledge.

Guy, C., and D. Bennison. 2007. "Planning guidance and large-store development in the United Kingdom: the search for 'flexibility'." Environment and Planning A 39 (4):945-964.

Hallsworth, A., R. de Kervenoael, J. Elms, and C. Canning. 2010. "The food superstore revolution: changing times, changing research agendas in the UK." The International Review of Retail, Distribution and Consumer Research 20 (1):135-146.

Holmes, T. J. 2011. "The diffusion of Wal-Mart and economies of density." Econometrica 79 (1):253-302. 
Hughes, R., A. G. Hallsworth, and G. Clarke. 2009. "Testing the effectiveness of the proposed UK “competition test'.” The Service Industries Journal 29 (5):569-590.

Jones, P. 1982. "Hypermarkets and superstores — saturation or future growth?" International Journal of Retail \& Distribution Management 10 (4):20-27.

Joseph, L., and M. Kuby. 2013. "Regionalism in US retailing." Applied Geography 37:150159.

Kantar Worldpanel 2013. Grocery share figures for the 12 weeks ending 7 July 2013.

Accessed at http://www.kantarworldpanel.com/dwl.php?sn=news_downloads\&id=248

Langston, P., G. P. Clarke, and D. B. Clarke. 1997. "Retail saturation, retail location, and retail competition: an analysis of British grocery retailing." Environment and Planning A 29 (1):77-104.

Langston, P., G. P. Clarke, and D. B. Clarke. 1998. "Retail saturation: the debate in the mid1990s." Environment and Planning A 30 (1):49-66.

Leahy, T. 2012. Management in 10 Words. London: Random House.

Lord, D. 2000. “Retail saturation: inevitable or irrelevant?” Urban Geography 21 (4):342360.

Leszczyc, P.T.L.P., Sinha, A. and Timmermans, H.J.P., 2000. "Consumer store choice dynamics: an analysis of the competitive market structure for grocery stores." Journal of Retailing 76 (3): 323-345.

Leszczyc, P.T.L.P., Sinha, A., Sahgal, A., 2004. "The effect of multi-purpose shopping on pricing and location strategy for grocery stores." Journal of Retailing 80 (2): 85-99.

McKinnon, A. C., D. Mendes, and M. Nababteh. 2007. "In-store logistics: an analysis of onshelf availability and stockout responses for three product groups." International Journal of Logistics Research and Applications 10 (3):251-268.

Morelli, C. 2007. "Further reflections on the golden age in British multiple retailing 1976-94: capital investment, market share, and retail margins." Environment and Planning A 39 (12):2993-3007.

Poole, R., G. P. Clarke, and D. B. Clarke. 2002a. "Grocery retailers and regional monopolies." Regional Studies 36 (6):643-659.

Poole, R., G. P. Clarke, and D. B. Clarke. 2002b. "Growth, concentration and regulation in European food retailing." European Urban and Regional Studies 9 (2):167-186.

Poole, R., G. P. Clarke, and D. B. Clarke. 2006. "Competition and saturation in West European grocery retailing." Environment and Planning A 38 (11):2129-2156.

Powe, N. A. 2012. "Small town vitality and viability: learning from experiences in the North East of England." Environment and Planning A 44 (9):2225-2239. 
CB Richard Ellis (CBRE) 2011. CBRE Marketview: Grocery Outlets in the Pipeline, December 2011

CB Richard Ellis (CBRE) 2012a. CBRE Marketview: Grocery Outlets in the Pipeline, July 2012

CB Richard Ellis (CBRE) 2012b. CBRE Marketview: Grocery Outlets in the Pipeline, December 2012

CB Richard Ellis (CBRE) 2013. CBRE Marketview: Grocery Outlets in the Pipeline, June 2013

The Independent 2012. "ASDA is cooling on hypermarkets as festive sales tick up", The Independent, Wednesday 22nd February 2012

http://www.independent.co.uk/news/business/news/ASDA-is-cooling-on-hypermarkets-asfestive-sales-tick-up-7280783.html

Reutterer, T., Teller, C., 2009. "Store format choice and shopping trip types". International Journal of Retail \& Distribution Management 37 (8): 695-710.

Reynolds, J., E. Howard, C. Cuthbertson, and L. Hristov. 2007. "Perspectives on retail format innovation: relating theory and practice." International Journal of Retail \& Distribution Management 35 (8):647-660.

Reynolds, J., E. Howard, D. Dragun, B. Rosewell, and P. Ormerod. 2005. "Assessing the productivity of the UK retail sector." The International Review of Retail, Distribution and Consumer Research 15:237-280.

Reynolds, J., and S. Wood. 2010. "Location decision-making in retail firms: evolution and challenge". International Journal of Retail \& Distribution Management 38 (11/12):828-845.

Retail Week 2012a. “Morrisons boss Dalton Philips' 'killer concept', Retail Week, 15 March 2012.

Retail Week 2012b. "Race for space must slow down”, Retail Week, 16 February 2012.

Roig-Tierno, N., A. Baviera-Puig, J. Buitrago-Vera, and F. Mas-Verdu. 2013. "The retail site location decision process using GIS and the analytical hierarchy process." Applied Geography 40:191-198.

J Sainsbury plc, 2012. J Sainsbury plc, Annual Report and Financial Statements 2012. Accessed at http://annualreport2012.jsainsbury.co.uk/media/22236/jsainsburys_annual_report.pdf

Sparks, L. 1986. "The changing structure of distribution in retail companies: an example from the grocery trade." Transactions of the Institute of British Geographers 11 (2):147-154.

Sparks, L. 1996a. "Challenge and change: Shoprite and the restructuring of grocery retailing in Scotland." Environment and Planning A 28 (2):261-284. 
Sparks, L. 1996b. "Space wars: Wm Low and the 'auld enemy'." Environment and Planning A 28 (8):1465-1484.

Sparks, L. 2011. "Settling for second best?: Reflections after the tenth anniversary of WalMart's entry to the United Kingdom." International Journal of Retail \& Distribution Management 39 (2):114 - 129.

Tesco plc 2006. Tesco Main Submission to the Competition Commission (Cc) Inquiry Into the UK Grocery Retailing Market, February 2006. Accessed at http://www.competitioncommission.org.uk/assets/competitioncommission/docs/pdf/inquiry/ref2006/grocery/pdf/mai n_party_submissions_tesco

Tesco plc 2013 "Retail destinations". Accessed at https://www.tescoplc.com/talkingshop/index.asp?blogid=102

Thompson, C., G. Clarke, M. Clarke, and J. Stillwell. 2012. "Modelling the future opportunities for deep discount food retailing in the UK." The International Review of Retail, Distribution and Consumer Research 22 (2):143-170.

Treadgold, A., and J. Reynolds. 1989. Retail Saturation: Examining the Evidence. Harlow: OXIRM, Longman.

Wang, H.-M.D., Bezawada, R., Tsai, J.C.C., 2010. "An investigation of consumer brand choice behavior across different retail formats." Journal of Marketing Channels 17 (3): 219242.

Weltevreden, J. W. J., and T. van Rietbergen. 2009. "The implications of e-shopping for instore shopping at various shopping locations in the Netherlands." Environment and Planning B: Planning and Design 36 (2):279-299.

Wood, S., M. Lowe, and N. Wrigley. 2006. "Life after PPG6: recent UK food retailer responses to planning regulation tightening." International Review of Retail, Distribution \& Consumer Research 16 (1):23-41.

Wood, S., M. Lowe, and N. Wrigley. 2010. "Conceptualising innovative customer-facing responses to planning regulation: the UK food retailers." The Service Industries Journal 30 (12):1967-1990.

Wood, S., and J. Reynolds. 2011. "The intrafirm context of retail expansion planning." Environment and Planning A 43 (10):2468-2491.

Wood, S., and J. Reynolds. 2012a. "Managing communities and managing knowledge: strategic decision making and store network investment within retail multinationals." Journal of Economic Geography 12 (2):539-565.

Wood, S., and J. Reynolds. 2012b. "Leveraging locational insights within retail store development? Assessing the use of location planners' knowledge in retail marketing." Geoforum 43 (6):1076-1087. 
Wood, S., and J. Reynolds. 2013. "Knowledge management, organisational learning and memory in UK retail network planning." The Service Industries Journal 33 (2):150-170.

Wrigley, N. 1991. "Is the golden-age of British grocery retailing at a watershed?" Environment and Planning A 23 (11):1537-1544.

Wrigley, N. 1994. "After the store wars: Towards a new area of competition in UK food retailing?" Journal of Retailing and Consumer Services 1 (1):5-20.

Wrigley, N. 1996. "Sunk costs and corporate restructuring: British food retailing and the property crisis." In Retailing, Consumption and Capital: Towards the New Retail Geography eds. N. Wrigley and M. Lowe. Harlow: Addison-Wesley Longman, pp 116-136

Wrigley, N. 1998. "Understanding store development programmes in post-property-crisis UK food retailing." Environment and Planning A 30 (1):15-35.

Wrigley, N., J. Branson, A. Murdock, and G. Clarke. 2009. "Extending the Competition Commission's findings on entry and exit of small stores in British high streets: implications for competition and planning policy." Environment and Planning A 41 (9):2063-2085.

Wrigley, N., K. Cudworth, and J. Li. 2012. The Impact of Small-Format In-Centre Foodstores on Small Towns (2011-2012). Southampton, Hampshire, UK: School of Geography, University of Southampton.

Wrigley, N., and L. Dolega. 2011. "Resilience, fragility, and adaptation: new evidence on the performance of UK high streets during global economic crisis and its policy implications." Environment and Planning A 43 (10):2337-2363.

Wrigley, N., D. Lambiri, and K. Cudworth. 2010. Revisiting the Impact of Large Foodstores on Market Towns and District Centres. Southampton, Hampshire, UK: School of Geography, University of Southampton.

Zhu, T., V. Singh, and M. D. Manuszak. 2009. "Market structure and competition in the retail discount industry." Journal of Marketing Research 46 (4):453-466. 